\title{
Galego na producción de Emilia Pardo Bazán
}

\section{Luis González García/Ma Rosario Soto Arias \\ Universidade da Coruña}

\section{Introducción}

Son innegables os pousos, en cada un distintos, que o galego deixa sobre os autores que utilizan o castelán como lingua literaria (Valle-Inclán, Torrente Ballester, Cela, por citar soamente os autores máis coñecidos e recoñecidos). Nesta nómina literaria, sen dúbida, a situación de E. Pardo Bazán é especialmente interesante. Entre outros motivos, pola súa inscrición en pleno século XIX, contemporánea pois do Rexurdimento e dos principais autores deste movemento dignificador da lingua galega. Debe terse en conta, ademais, que a novela española da segunda metade do século XIX era fortemente rexionalista (Pereda, Clarín, Valera, Fernán Caballero, Juan Valera...) e gustaba de reproduci-la fala local. No caso de E. Pardo Bazán, unha escritora aristocrática e de rexa personalidade, todos estes factores entrecrúzanse dun xeito que merece un estudio.

O noso interese céntrase sobre todo no aspecto linguiístico da producción da ilustre autora coruñesa. Non obstante, cumprirá que dediquemos unhas escasas páxinas a presentar a relación, non exenta de conflicto, mantida por Pardo Bazán con respecto a Galicia, a súa realidade e a súa lingua.

Para realizar este labor, empezaremos mostrando algúns feitos significativos da súa relación coa terra natal, para continuar analizando a postura persoal da autora diante do fenómeno de convivencia de dúas linguas en Galicia. A continuación, veremos como se manifesta esta actitude na súa obra literaria, paso necesario para poder determinar ata onde chega a súa coherencia.

\section{E. Pardo Bazán e Galicia}

A pesar do carácter cosmopolita da Condesa de Pardo Bazán, da súa residencia na capital do Estado desde tempos mozos (onde ocuparía importantes -e discutidos-

1 Este traballo é unha versión considerablemente ampliada da comunicación, breve por necesidade, presentada co título de "E. Pardo Bazán, sociolingüista" no IV Congreso Internacional de Estudios Galegos (Universidade de Oxford, setembro de 1994) e publicada nas correspondentes Actas editadas por B. Fernández Salgado, Oxford Centre for Galician Studies, 1997, T. I, 519-539.

As siglas que acompañan as citas aparecen explicitadas na bibliografía final. Nas citas mantéñense as cursivas e comiñas orixinais. Os autores deste traballo resaltaremos algunha palabra mediante letras negriñas. 
cargos na Administración, na Universidade ou en organismos culturais), a pesar das súas viaxes prolongadas polo estranxeiro (especialmente por Francia) e dos seus contactos cos principais autores do momento, é necesario recoñecer que a vida e a producción de $\mathrm{D}^{\mathrm{a}}$ Emilia é inseparable da súa orixe galega.

A autora, desde as súas primeiras composicións, mostra ata que punto é capaz de indagar na realidade galega. Sen dúbida, este carácter innato de apego á realidade inicial viuse favorecido pola súa extraordinaria intelixencia e polos dotes observadores que permitiron tirar todo o partido posible do que a fortuna material familiar lle deparou: educación esmerada, contacto desde a infancia cos próceres da política naquel axitado tempo, residencias e pazos espallados polo territorio e a conseguinte posibilidade de viaxar (excursións, invitacións, conferencias). Deste xeito, toda a realidade galega aparece directamente -sen intermediarios- diante dos seus ollos.

Neste sentido, partindo da súa producción literaria ou xornalística é posible acadar un vivo fresco, quizais máis próximo ó realismo que ó naturalismo, da Galicia contemporánea ${ }^{2}$. Por diante das páxinas escritas por E. Pardo Bazán pasa toda a sociedade galega da época: a das cidades, como Santiago -Estela- e principalmente A Coruña -Marineda-, coa clase nobre na cidade vella, a burguesía dos barrios novos, a nova clase obreira dos suburbios, máis abaixo aínda a poboación rural que se levanta rompendo o día para acudir ós seus ínfimos traballos na cidade ou vende-los seus productos. Boa parte da producción literaria da nosa autora desenvólvese en Marineda: La Tribuna, Doña Milagros, Memorias de un solterón, La piedra angular, Cuentos de Marineda, etc. Dona Emilia é amiga da observación directa, como os novelistas da súa xeración. Así asiste durante meses á fábrica de tabaco da Coruña para a elaboración de La Tribuna ${ }^{3}$.

O mundo rural e mariñeiro tampouco lle era descoñecido, como non o era tampouco o das pequenas vilas ou o dos pazos e aldeas rurais. As súas estancias nas Torres de Meirás, situadas na terra das Mariñas, cerca de Sada (Areal) ou nas Torres de Miraflores (Pazo de Portodor), cerca da Toxa, preséntanlle este mundo do mar con tódolos seus tipos (desde os máis miserables ós emprendedores empresarios de orixe catalana dedicados á salgadura ${ }^{4}$ ). La sirena negra, Una cristiana, La prueba, La Quimera, así como unha boa parte dos seus contos, ambiéntanse neste marco.

2 Para unha análise da realidade galega desde unha perspectiva sociolóxica remitimos a Paredes Núñez (1983) e a Velasco Souto (1987).

3 Incluso nas súas obras situadas en Madrid (Insolación, Morriña) mostra outra parte de Galicia, a da emigración (nas súas distintas clases sociais).

4 Miguel aguardaba en su despacho comercial de aspecto árido, polvoriento. Allí pasaba el joven fabricante interminables horas uncido a su trabajo, ahorrándose cajero y dependiente, según el encogido sistema de su padre, el viejo Amorós, fundador de la fortuna de la familia, y que tenía por máxima que «el dinero lo cría el sudor» (CNT 514). 
O matrimonio con D. José Quiroga e Pérez Deza acércaa á Galicia do interior (principalmente á ribeira do Avia e do Arenteiro, fundidos no Avieiro, nas terras que circundan O Carballiño -Vilamorta-, próximas ó Pazo de Banga propiedade dos Quiroga). Neste marco transcorre quizais a máis destacada producción da autora: Bucólica, El cisne de Vilamorta, gran cantidade de contos e, sobre todo, Los Pazos de Ulloa e La Madre Naturaleza.

Como dixemos anteriormente, o resultado é a presentación dun cadro complexo da sociedade galega do momento, das súas clases sociais, da situación económica (a decadencia dos pazos, o minifundio, a burguesía emerxente), da forma de vida (costumes, feiras, romarías, alimentación, vestimenta, supersticións, rivalidades paroquiais, etc.).

Neste punto, Emilia Pardo Bazán convértese nunha auténtica etnógrafa obxectiva que mostra na súa obra literaria unha realidade que quizais nos parecese incrible de non contarmos coas crónicas periodísticas en que desenvolve os mesmos feitos.

Unha das características más salientables de Emilia Pardo Bazán, especialmente na España da época, o seu acentuado feminismo, quizais se puidese xustificar partindo desta análise, deste contacto coa sociedade real (tan afastada do ambiente selecto da alta sociedade a que ela pertencía). Referímonos especialmente á situación da muller nas capas baixas da sociedade. Nestas, a súa independencia é maior e aínda máis, probablemente, na galega. Como escribe ela en La mujer española:

Hoy por hoy, existe en la mujer de clase media y la del pueblo español este abismo profundo; la del pueblo tiene la noción de que debe ganar su vida; la burguesa cree que ha de sostenerla exclusivamente el trabajo del hombre. De aquí se origina en la burguesa mayor dependencia, menos originalidad y espontaneidad (cit. por Varela Jácome 1995: 28).

Outra faceta importante da nosa autora é o seu interese pola vida cultural (científica, literaria) da súa época e o seu gusto por relacionarse coas principais figuras literarias. Neste apartado, os coñecidos estudios sobre a literatura francesa, rusa ou do resto do país alternan cos máis directamente vencellados a Galicia é o galego. A este punto dedicaremos o apartado seguinte, pero antes convén que mencionemos, polo que afecta ó núcleo do noso estudio, a súa importancia como dinamizadora dos estudios folclóricos en Galicia. Sabido é que, por iniciativa de A. Machado Álvarez, a ela se debe a creación da "Sociedade de Folclore Gallego", da que foi

5 Puedo decir que la naturaleza de este país me es más familiar todavía que la de mis Mariñas natales [...]. Aquí tienen su escenario la mayor parte de mis novelas.

Tengo a la provincia de Orense por la más bella de Galicia -sin exceptuar a la de Pontevedra, aunque la mayor parte de los turistas no opina así- pero hay que verla cuando la uva cuelga, ya sazonada... (DMT 187). 
presidenta, e a colaboración na Biblioteca de las Tradiciones Populares Españolas e noutras revistas. Na súa producción literaria abunda este tipo de información: lendas $^{6}$, supersticións ${ }^{7}$, costumes ${ }^{8}$ e actividades colectivas 9 , etc. Polo mesmo non poden faltar modismos, refráns, cantigas populares. Daremos uns poucos exemplos extraídos de La Madre Naturaleza:

Nesa obra Manuela quere conseguir que unha boíña levante o voo co seguinte recitado:

Mariquiña, voa, voa, que ch'ei de dar pan e ceboa $(M N 152)^{10}$.

${ }^{6}$ Ahí, en Penamoura, cuentan que enterraron los moros un tesoro muy grandísimo (CNT 80).

7 O aire cativo da "salmántiga" (CNT 466-470) aínda causa repeluxe en quen se criou -como é o caso de quen isto escribe- un século máis tarde que dona Emilia.

En Madre Naturaleza non escasean as referencias:

Antaño, predominando el sexo femenino, se pagaba tributo muy crecido a la superstición: se refería el paso de la Campaña con su procesión de luces; se contaban las tribulaciones de la mocita a quien le habían dado sombra de gato negro o atacádola el ramo cativo; se of recían recetas y medicinas para todos los males [...] y las mozas en ratos de buen humor se tiroteaban a coplas, improvisándolas nuevas cuando se le acababan las antiguas ( $M N 254)$.

A la presente estamos aquí platicando los dos; pues cata que sale una mosca verde del estiércol y te pica..., el caruncho sea contigo, y acabóse (MN 291).

8 Campesinas mozas vemos que tienen la balsámica frescura de las hierbas puestas puestas a serenar la víspera de San Juan ( $M N$ 126).

En ocasións sorprenden os pequenos detalles, como o seguinte precedente do seguro médico:

Su madre, al verle moribundo, se decidió a avisar al médico, con quien estaban arrendados por seis ferrados de trigo anuales (CNT 174).

9 Algúns labores son ben coñecidos, como a malla, pero coas súas peculiaridades:

No siendo de piedra la era, habíanla barnizado con una costra espesa de boñiga de vaca, a fin de que el fruto no se conf undiese entre la arena y el polvo, y, rodeándola de sábanas sostenidas por cuerdas, con objeto de que el mismo grano no rebasase del circuito donde se majaba. Las camadas de pan, ópimas, gruesas, mullidas, se tendían sobre el espacio cuadrilongo, en correcta formación; y los membrudos gañanes, remangados, en dos hileras situadas frente a frente, aporreaban con sus pértigas, a compás, la extendida mies ( $M N 225)$.

Outras actividades chaman máis a atención: en "La ganadera" (CNT 476-479) describe unha antiga práctica-¿quen sabe se existente?- para provocar naufraxios.

${ }^{10}$ Que recorda un "Voa, boíña, boa, que che hei de dar pan e broa" aprendido por nós na infancia.

Na novela curta Finafrol menciónase outro recitado popular:

Sin embargo, cuando Mariano formuló sus dudas acerca de la duración de la vida, un canto característico se oyó entre el denso ramaje. Era el del cuco - profeta, el cuco que dice los años que se ha de vivir-, y Miguel, llevado por instinto indefinible, lanzó a su hermano un emplazamiento:

-Eso de si despertarás o no, pregúntaselo al cuco-rey...

Mariano recordó la superstición aldeana, y alzando la gentil cabeza hacia la copa del árbol, interrogó al ave:

-¿Cuántos años «vivirey»?

Al punto mismo, un claro gemido aflautado repetido, el disílabo «icu! $; c^{\prime}{ }^{\prime}$, salió de entre el verdiazul ramaje [...]. El cuco no volvió a cantar.

-Ya lo ves -dijo Mariano [...]. El profeta me anuncia que moriré este año (CNT 507).

A profecía cúmprese en poucos días. 
Na mesma obra, lemos:

Goros tenía cuidado de levantarse por la mañana muy temprano y de despertar a su amo, pues según decía él en dialecto, demostrando su pericia en asuntos de la vida eclesiástica, el clérigo y el zorro, si pierden la mañana, lo pierden todo ( $M N$ 168).

O refrán mencionado aparece coas mesmas palabras en repertorios casteláns (por exemplo, Martínez Kleiser 1989: 652), pero tamén noutros galegos con lixeiras variantes "O crego e o raposo, se perden a mañá perden o día todo" (Ferro Ruibal 1987: 557; Zamora Mosquera 1972: 165). Evidentemente, sería este o repetido por Goros en dialecto.

Finalmente, tampouco faltan referencias ás coplas populares. Ó anoitecer, trala malla,

Una tanda de mozas y mozos bailaba el contrapás al son de la pandeireta y la flauta; la tañedora de pandero cantaba esta copla:

A lua vay encuberta, a min pouco se me da:

a lua que a min m'alumbra

dentro do meu peito está $(M N 257)^{11}$.

\section{E. Pardo Bazán ante o galego}

Na amplísima producción intelectual de E. Pardo Bazán non escasean as referencias en que dá conta da súa postura ante o galego, a súa literatura e cuestións intimamente relacionadas. Neste sentido son sobradamente esclarecedores os artigos que en 1888 recompilou no libro De mi tierra, especialmente os que abren e cerran a obra ("La poesía regional gallega" e “¿Idioma o dialecto?”, respectivamente).

Da lectura destes artigos despréndese unha visión que nos relembra a dicotomía que se manifesta nalgunhas das súas obras máis logradas: o conflicto entre a Civilización e a Natureza, que os críticos coinciden en sinalar como un dos temas fundamentais de títulos como Los pazos de Ulloa ou La madre naturaleza, revive se se considera a situación lingüística e social de Galicia. Para dona Emilia, o gale-

11 A copla está tirada do Cancionero popular gallego de J. Pérez Ballesteros (T. I 8), publicado en 1886 tamén na Biblioteca de las tradiciones populares españolas, do que a autora fai un acendido estudio recollido en De mi tierra (DMT99-120). O material deste traballo utilízao igualmente na obra que aquí nos ocupa:

Las coplas populares no celebran jamás la belleza de la mujer después de casada y madre; sus requiebros y ternezas son siempre para las rapazas, las nenas bunitas ( $M N 126)$. 
go é a natureza; o castelán, a civilización; ou se queremos, son nai e pai, o mundo afectivo fronte ó mundo intelectual:

A los poetas regionales los comprendemos y sentimos de un modo estrecho y personal: nos hablan de cosas muy próximas al alma, cosas que no se olvidan por más azares que la existencia traiga consigo y por muy lejos que nos arroje la suerte del rincón donde se abrieron á la luz nuestros ojos: nos envuelven en la atmósfera natal, tibia como el claustro materno: compendia su musa lo pintoresco de nuestras costumbres y lo añejo y venerado de nuestras tradiciones: son la infancia, son la fe, son la ternura... (DMT 16).

Unha situación como esta, evidentemente, non crea conflictos persoais: os ámbitos de ámbalas linguas están ben repartidos (co-linguiismo); ela séntese membro do que representa a cultura:

Y el dialecto [continuamos a cita anterior, a pesar da súa lonxitude, mais é ben explícita], aun en países como el nuestro, donde las clases educadas ni lo hablan ni lo escriben, posee un dejo grato y fresquísimo [...] pues, con ser el castellano nuestro verdadero idioma [itálica nosa], siempre sentimos la proximidad del dialecto, que lo ablanda con su calor de hogar, que modifica el acento y la pronunciación, que impone el giro, el modismo, el diminutivo... (DMT 16).

E. Pardo Bazán fala, pois, desde unha posición en que, como actitude persoal e tamén colectiva, acepta o castelán como lingua propia, relegando o galego ó ámbito sentimental (por eso mesmo mostra as súas preferencias pola poesía folclórica e costumista e prefire a Rosalía de Cantares gallegos á de Follas novas e Pondal a Curros $\left.^{12}\right)$.

Por esta razón, o emprego do galego (e dos demais "dialectos" españois) non debe pasar de determinados límites:

Merced á la curiosidad que hoy inspiran las literaturas regionales, el florecimiento de los dialectos y la vida provincial; por este impulso de descentralización que, contenido en sus justos límites, es recto y sano, quizás posean algún atractivo para el lector español los folios de esta obrilla (DMT 9).

¿Que debemos entender por “justos límites”? A “unidade da patria”, valor superior:

...el renacimiento lleva en sí un germen de separatismo, germen poco desarrollado todavía, pero cuya presencia es imposible negar, y que acaso sea el único fruto político y social de este florecimiento poético ¡Qué otra cosa significa la frecuente confusión del concepto de patria con el de tierra o región nativa [...]

12 Son ben coñecidas as fortísimas críticas que M. Murguía e mais Curros Enríquez lle dirixiron á nosa autora. Curros en $O$ divino sainete caracterízaa pola envexa ("D’a envidia estás frente a frente") e pola fealdade ("Certa literata fea") (Véxase Curros Enríquez 1969: 70 e 43 respectivamente). 
Galicia no es sino la tierra, algo íntimo y dulce, algo quizás más caro al corazón, más necesario para la vida que la misma patria pero la patria representa una idea más alta aún, y la patria, para los españoles todos [...] es España, inviolable en su unidad, santa en sus derechos (DMT 40).

Por máis que o seu sentido crítico lle dicta que, se nalgún lugar é perdoable ese pecado é en Galicia por canto

Quejaránse Cataluña, las Vascongadas y Aragón de la pérdida de sus privilegios, fueros, exenciones é inmunidades; mas su misma que ja prueba que alguna vez las poseyeron, mientras nuestras provincias han sentido, desde tiempo inmemorial, pesar sobre sus hombros la ley común, sin un solo momento de alivio, ni la protección que requería su pobreza y las calamidades que alguna vez la desolaron (DMT 41).

Non faltan no libro que estamos comentando alusións doutra índole, quizais de maior interese por canto mostran unha análise crítica da realidade mísera de Galicia (social e cultural) e das súas causas, paso previo necesario para ofrecer solucións. A ilustre coruñesa dáse de conta de que na orixe da situación galega hai unha especie de determinismo de causas e efectos: só o cultivo literario pode lograr que unha lingua acade un desenvolvemento e cultivo efectivo, non hai literatura sen unha clase social e infraestructura que a manteña. En Galicia non se cumpre ningunha das tres condicións. Faltan infraestructuras:

Dígase lo que se quiera, el estado material de los países se refleja tarde ó temprano en la intensidad de su vida literaria, y ésta, en Galicia, ha sido y es lánguida y trabajosa, no por incapacidad de la raza, sino por consecuencia ineludible del abatimiento general en que la desventura, y la apatía que engendrar suele, nos tienen sumidos. ¡Tan cierto es que la Musa moderna [...] no prefiere las ruinas, el atraso y la muerte moral de los pueblos postrados é inactivos, sino que ama el gemir de la prensa, el estruendo del trabajo, la riqueza, pedestal de oro del Arte! (DMT 21-22).

Falta unha clase social ilustrada que cultive o galego:

$\mathrm{Al}$ afirmar que el atraso de la lengua gallega nace de su carencia de literatura, no me refiero solamente á las bellas letras. También es cultivo literario para un idioma la conversación entre gentes instruidas, el comercio epistolar, la oratoria sagrada y profana, los instrumentos públicos; y en Galicia esto se hace en castellano. No así en Cataluña, donde todas las clases sociales, para todos los usos de la vida, se sirven del habla provincial; por eso allí un leve chispazo bastó a encender la inmensa hoguera de la renaixensa (DMT 19).

Tense dito con certa frecuencia que dona Emilia era excesivamente benévola coa súa clase social. Non é de todo exacto: nas súas obras transloce claramente como o absentismo e abandono das casas matriciais é unha das causas principais da ruína do país. A queixa faise explícita en ocasións: 
Aun sería tiempo de que las clases ilustres por sangre y tradición recobrasen amplia y legítima influencia, comparable á la que en Inglaterra ejercen; y contribuiría a este objeto que reinstalándose en sus antiguas viviendas, arrojasen de ellas a las lechuzas y los grajos, reparando los estragos del tiempo devastador y esparciesen [...] los beneficios de la cultura y el dinero de sus rentas pingües en el país de cuyos frutos las cobran (DMT 249).

Ela, sen dúbida, intentou realizar tan loable propósito.

Resumindo, a postura de E. Pardo Bazán ante o galego foxe dos conflictos e enfrontamentos, repartíndose uns amores que con frecuencia son difíciles de compartir. Non podemos evitar que nos recorde a coñecida cita de Rubén Darío: "mi esposa es de mi tierra; mi querida, de París". Vexamos como se cumpre este propósito na súa obra.

\section{O galego na obra literaria de E. Pardo Bazán}

E. Pardo Bazán menciona nos seus Apuntes Autobiográficos, que preceden a edición de Los pazos de Ulloa, que a súa decisión de escribir novelas obedecera á lectura dos autores contemporáneos "Si la novela se reduce a describir lugares y costumbres que nos son familiares, y caracteres que podemos estudiar en la gente que nos rodea, entonces (pensé yo), puedo atreverme; y puse manos a la obra".

O seu xenio non se sentía predisposto para segui-lo camiño das lecturas primeiras, dos autores románticos, cheas de peripecias e aventuras inverosímiles, e ambientadas en épocas remotas.

Cuestión transcendental no movemento realista foi a procura dunha linguaxe verosímil (o que os retóricos denominan decoro) na que cada personaxe falase de acordo coa súa condición. Deste xeito, Galdós dá entrada á linguaxe familiar de Madrid e outros autores retratan a fala dialectal das respectivas comunidades: Asturias (Clarín, nalgúns contos e novelas curtas), Santander (Pereda), Andalucía... No prólogo de La Tribuna E. Pardo Bazán recoñece esta débeda:

En abono de La Tribuna quiero añadir que los maestros Galdós y Pereda abrieron camino a la licencia que me tomo de hacer hablar a mis personajes como realmente se habla en la región de donde los saqué. Pérez Galdós, admitiendo en su Desheredada el lenguaje de los barrios bajos; Pereda, sentenciando a muerte a las zagalejas de porcelana y a los pastorcillos de égloga ( $T$ 9).

Agora ben, para a autora galega preséntase un problema polo que non se vían afectados os anteriores autores: a realidade lingüística de Galicia, o decoro, esixía que os seus personaxes non falasen en castelán, polo menos en certas ocasións. Deixemos falar de novo dona Emilia: 
El campo me gusta tanto, que mi aspiración sería escribir una novela donde solo figurasen labriegos; pero tropiezo con la dificultad del diálogo, tan inmensa, que Zola, el novelista de los atrevimientos, no osa arrostrarla, según acabo de leer en un periódico, y a los campesinos que describe en su obra actual, La Tierra, no les hace hablar en patois, sino en francés. Todo lo puede el genio, y Zola orillará la dificultad; pero yo siento que las cosas gráficas, oportunas y maliciosas que dicen nuestros labriegos son inseparables del viejo latín romanzado en que las pronuncian, y que un libro arlequín, mitad gallego y mitad castellano, sería feísimo engendro (Cit. apud CNT 18).

Pardo Bazán rexeita, pois, solucións como a de Maxina, en que se dera cabida á lingua autóctona en alternancia coa oficial. Por outra banda, cando ela comeza a súa producción novelística, o galego aínda carece de cultivo no xénero narrativo. Evidentemente, ela non ía abrir este camiño porque pola súa formación e ideoloxía o seu mundo -e o seu público- é o da literatura en castelán.

Para resolve-lo problema opta por unha solución sumamente acertada, en que se manifesta cumpridamente o seu xenio novelístico e observador: en lugar de alternar as dúas linguas sen confundirse (como nos cadros do traxe arlequinesco), crea unha lingua mixta, como o pan de mestura que con frecuencia comen os seus labregos, un castrapo en que o castelán en que a autora compón a obra é pasado pola peneira da linguaxe real dos personaxes.

Esta linguaxe é creación artística da autora, pero a base é a observación da realidade. Non será necesario traer en confirmación algunha das abundantes citas en que -con dor e saudade do pasado- se alude a esa lingua chapurrada que se estendía polo país. Abóndenos unha de Murguía, coincidente no tempo (1904):

Cuando recorre uno el centro de Galicia, hasta ahora libre de la influencia que el tráfico y las demás relaciones de la vida imponen en las poblaciones del litoral, se advierte de golpe, que aquellos lugares hasta hoy cerrados y refractarios al lengua je castellano, empiezan a abrirles las puertas y cuando menos tienden a modificar el idioma gallego con detrimento de éste, tanto como de la lengua de Castilla, que padece no poco, al pasar por labios que jamás la usaron (Cit. por M. Portas 1991: 86).

O mérito de Pardo Bazán na creación desta lingua é, ó noso parecer, dobre. Dunha parte artístico: M. Mayoral recoñece que nela "no resulta 'feísimo engendro' sino instrumento eficacísimo para caracterizar a sus personajes campesinos" (CNT 18).

En efecto, a mestría con que Pardo Bazán selecciona e condensa os trazos pertinentes dá lugar a un producto totalmente verosímil e harmónico con respecto ó mundo narrativo descrito. O resultado caracterízase por un dramatismo que a arreda do mero folclorismo sen perder plasticidade. A lingua convértese, deste xeito, nun instrumento esencial nas obras ambientadas en Galicia. 
O segundo mérito de Pardo Bazán apunta cara á sociolingüística. O logro da verosimilitude esixe que o uso lingüístico se axuste ás circunstancias exteriores (situación, nivel sociocultural dos interlocutores). Pardo Bazán logra esta adecuación fuxindo de acomodos simplificadores.

Dixemos que a mencionada lingua procede da observación persoal. A condesa coñecía perfectamente a sociedade galega, en tódalas capas sociais, en toda a súa xeografía: o mundo rural do interior (Ourense) e da costa (as Mariñas natais, as Rías Baixas), as vilas (Vilamorta, Areal), as cidades (Marineda, Estela, Auriabella). A dona Emilia gustáballe falar coa xente humilde e era grande amiga das excursións pola xeografía galega nun tempo en que non era doado moverse polo país ${ }^{13}$. Todo este coñecemento maniféstase na súa ampla producción na ambientada no mundo urbano e no rural.

\subsection{O mundo rural}

Evidentemente, é no mundo rural onde a influencia do galego se mostra con máis forza. Os labregos, mendigos ou mariñeiros das súas obras teñen o galego por lingua de uso cando falan entre si. A autora salva a verosimilitude da súa expresión nun castelán máis ou menos axeitado mediante o recurso da traducción: os labradores falan en galego, non nesta lingua que o narrador ás veces non fai máis que medio traducir para que conserve a cor local. E. Pardo Bazán non nos mostra como realmente falan estes personaxes senón como falarían se se intentasen expresar en castelán, na lingua en que está escrita a obra. En múltiples ocasións E. Pardo Bazán alude a esta conversión:

-¡El Arco de la Vieja! -exclamó en dialecto la niña (MN 13).

La abuela [...] le dio un pequeño lapo para que se apartase, y en dialecto explicó, repitiendo cada cosa cien veces y con las mismas palabras, que los chiquillos eran unos demonios, que a éste y a su hermana los había tenido que encerrar en el sobrado para poder cocer...(MN 160-161).

-Venga conmigo, se la enseñaré -contestó en dialecto el muchacho... ( $Q$ 140).

Crispó los puños, se atizó un recio golpe en la frente, miró al manso borrico, y murmuró en dialecto:

-Aún soy yo más (CNT 174).

Entreoí la fórmula gallega clásica:

-De hoy en cien años (I 53).

1.3 Basta recordar as liñas iniciais de Los Pazos de Ulloa e os capítulos V e VI de La madre naturaleza para facerse unha idea de como era o camiño real de Santiago a Ourense, por ela tantas veces transitado, e as difíciles condicións das viaxes por el. 
O realismo aumenta cando o campesino se dirixe a un superior. Agora si é probable que tente falar na lingua do seu interlocutor dun xeito que se aproxime ó resultado que a autora reproduce. Os casos sociolinguiísticos complícanse aquí, porque agora nos atopamos ante unha situación real de diglosia en que interveñen factores diversos (diafásicos e diastráticos): o nivel sociocultural dos interlocutores, a situación formal ou coloquial, privada, pública ou solemne, etc.

Este entrecruzamento de situacións resólveo Pardo Bazán con acertada mestría. En primeiro lugar, o nivel sociocultural do interlocutor é inversamente proporcional á interferencia entre as dúas linguas en contacto:

a) Os poucos personaxes ilustrados que aparecen -a burguesía das cidades, algún clérigo instruído- sempre falarán en castelán (salvo que reproduzan en estilo indirecto unha conversación ou se intenten adecuar ó nivel dun inferior):

-Señora mi ama, no me afago aquí.

-Y pasado algún tiempo, ¿no te afarás tampoco?

-Tampoco. No, señora (CNT 178).

[véxase máis adiante o diálogo entre o abade de Gondás e a señora Antonia, en Atavismos].

Como máximo, a influencia que o galego exerce sobre esta clase social redúcese a algún termo illado, algún diminutivo ou expresión afectiva, ou algún termo localista difícil de traducir ó castelán:

-Toma, rapaciño... A ver si me pierdes el miedo

dille Nucha a Perucho ( $P U$ 137), intentando ser cariñosa co rapaz.

-Mulleriña, no vengo a molestar... Vengo a preguntarle si quiere que la atienda (CNT 368)

di un esforzado relixioso a unha pobre leprosa deixada nunha illa.

O uso do galego nestes casos sempre conleva unha segunda intención, frecuentemente interesada. Así, por exemplo, D. Manuel Pardo de la Lage (membro da nobreza urbana compostelá) dille ó seu sobriño, P. Moscoso:

Cuidado que estás más hombre que yo... Siempre te imitaste más a Gabriel y a mí, que a tú madre... (PU 83).

En opinión dalgúns críticos este emprego de imitar non é máis que un risco de color local. Hai que ter en conta, sen embargo, que dona Emilia prepara a situación: D. Manuel "le habló llanamente, para inspirarle confianza" ( $P U$ 83). O mesmo ambiente coloquial repítese noutra alusión ó seu emprego do galego: 
Dio al sobrino manotadas en los hombros y en las rodillas; gastó chanzas [...] y, por último, tras referir varios chascarrillos adecuados al asunto y contados en dialecto, acabó por declarar que a las demás chicas les daría algo al contraer matrimonio, pero que a Nucha... (PU 234).

É unha utilización consciente: o seu sobriño, no fondo, pertence ó mundo rural, e don Manuel quere capta-la súa benevolencia porque ten sumo interese en poder casar algunha das súas fillas co nobre rural. Demostra, pois, un emprego diglósico que relega o galego a situacións especiais.

b) No nivel intermedio (pequenos fidalgos, curas aldeáns, caciques que, a pesar do seu poder social, carecen da suficiente formación como ocorre tamén coa nobreza rural decadente dos pazos), a interferencia linguiística é maior. Con todo, o seu frecuente contacto co mundo que se expresa en castelán permítelles un dominio máis ou menos aceptable deste, lográndose así que os límites entre as dúas linguas non esvaezan. Por esta causa a interferencia afecta sobre todo ó léxico (a parte da lingua que menos defensa opón á invasión lingüística, aquela por onde empeza o socavamento do sistema):

Oiamos a morgada de Valdelor:

... Y luego, ¿María Lorenza y yo íbamos a quedarnos sentadas o a fecharnos en el desván? (CNT 80).

Ou a conversa do arcipreste de Loiro e o cura de Morais (CNT 396):

-Entonces, el rapaz, encontrástelo detrás de un tojo, ¿eh?

$[\ldots]$

-Hom, poco menos [...] salto a cortar una vara con la navaja, cuando oigo un llanto de chiquillo pequeño. Miro por todas partes y allí estaba el rapaz [...] Miré por todas partes, pensando que la madre andaría por allí [...]. Anduve arreo un cuarto de legua, preguntando en todas las casas [...]. En una casa me dieron por caridad una cunca de leche...

Esta clase intermedia é interesante pola súa heteroxeneidade: os cregos de aldea, por exemplo, non son todos iguais nin todos incultos, móvense nun medio que está en contacto tanto coas clases elevadas como coas populares. Lingüisticamente, por tanto, han poder comunicarse con ámbolos mundos (diglosia). Así lle sucede, por exemplo, ó cura de Naya, que conta ó narrador (presumiblemente a condesa) unha violenta historia de caciques. No medio reproduce unha conversa mantida cun labrego, que suscita un comentario cara ó narrador:

"Andrés, adónde vas con el cuxo? Feria hoy no la hay." [...] "Señor abad, por el alma de quien le parió, no diga nada. El cuxiño es para ese condenado de Lobeiro, que me lo mandó pedir [...]”. Y el pobre hombre, cuando me lo decía, tenía los ojos como dos tomates, encarnizados de llorar. ¡Ya comprende usted lo que es para el labriego su ganado! Dar aquel ternero era, en plata, dar las telas del corazón (CNT 206). 
O cuxo dirixido ó labrego, convértese nun ternero cando varía o interlocutor. Esta situación de dimorfismo (expresión galega en boca dun personaxe de clase baixa, traducción ou equivalencia en castelán por parte doutro de situación socioeconómica superior ou mesmo por parte da autora) é abundante na producción examinada. Así, no conto "La Camarona" o don Camilito mencionado pola autora convértese nun don Camiliño na intervención da nai da protagonista, pobre pescadora (CNT 202). Vexamos algún exemplo máis:

En "Consuelos", María Vicenta, costureira que acaba de perder un neno de curta idade, dille a Selme, que acaba de traerlle a caixa (cajón) en que enterralo:

-Selme [...], coge ahí de la lacena una botella que hay mediada y echarás un vaso.

No hubo que decirlo dos veces. Mientras Selme revolvía la alacena, fueron entrando comadres y mocitas aldeanas (CNT 49).

En ocasións a alternancia non é léxica senón gramatical, como comprobamos na seguinte cita de "La mayorazga de Bouzas", en que dialoga a mencionada morgada co seu criado, Amaro:

-[...] El señorito no "va" en Resende.

-¿Qué no está en Resende mi marido?

-No, señora mi ama, con perdón $[\ldots]$

-¿Pues dónde está?

-Estar... estar, estará donde va cuantos días Dios echa al mundo.

- ¿Adónde va todos los días? (CNT 155).

Tampouco deixan de ser interesantes aqueles casos en que é un mesmo personaxe o que ofrece os dous resultados segundo a categoría do interlocutor. Deste xeito, Bico de Rato, cazador furtivo, usa tórtolas en conversación co marqués e cos cregos pero non na conversa cunha nena aldeana, que reproduce:

Venía yo de tirar a las tórtolas en un sembrado, y me encontré a la chiquilla del tío Pepe, de Naya, que traía la vaca mismo cogida así [...]. "Buenos días." "Santos y buenos.” “Me da las rulas?” “¿Y qué me das por ellas, rapaza? (PU 203).

Estas interferencias non poden ser alleas, evidentemente, ós grandes señores rurais. En La madre naturaleza compróbase o abandono en que se ten a educación de Manuela. Don Pedro Moscoso, o señor de Ulloa, usa expresións galegas con relativa frecuencia, especialmente cando trata cos criados, cos inferiores a el socialmente:

¡Ea! ¡Day un jarro de vino, retaco! Los majadores tenemos que mojar la palabra! (MN 227).

Coñece a equivalencia fonética [] galega / [x] castelá, pero ignora que na palabra mallador non se cumple. En Castela non se maja senón que se trilla. Pero tamén con xente da súa clase (o seu cuñado Gabriel de formación cosmopolita): 
Y desde las cuatro de la madrugada hasta las ocho de la noche llevaba aguantada toda la lluvia, que se me había secado encima del cuerpo [...] y todo el frío, y todas las brétemas, y los orvallos $[\ldots]$ ¡Cuántas noches de invierno tengo salido a las liebres que andaban pastando por las viñas! (MN233).

Evidentemente, sempre é posible o ascenso social, incorporándose á clase alta individuos procedentes das inferiores. $\mathrm{O}$ conflicto lingüístico nestas circunstancias acrecéntase. No caso contrario do cura de Naya tópase Ángel de Naya (alcumado El Gallo) que por casamento logra ascender na escala social ("Labriego trasplantado a una capa superior, todo el afán del Gallo era subir más, más aún, en la escala social", $M N$ 127). Entre as novas marcas de identidade figura o abandono da lingua materna. É o caso prototípico de conflicto entre dúas linguas e os valores que representan. Desgraciadamente, o empeño de Ángel non era doado, como recorda a clasista dona Emilia:

También era para él gran preocupación el hablar, pues se esforzaba en que sus labios olvidasen el dialecto a que estaban avezados desde la niñez, y no pronunciasen sino un castellano que sería muy correcto si salvásemos las innumerables jeadas, contracciones, diptongos, barbarismos y otros lunarcillos de su parla selecta. ¡Y cuanto más se empeñaba en sacudirse de los labios, de las manos, de los pies, el terruño nativo, la oscura capa de la madre tierra, más reaparecía, en sus dedos de uñas córneas, en sus patillas cerdosas y encrespadas, en sus muñecas huesudas y en sus anchos pies, la extracción, la extracción indeleble que le retenía en su primitiva esfera social! Si él lo comprendiese, sería muy infeliz. Por fortuna suya creía todo lo contrario ( $M N$ 128).

Como consecuencia, a Condesa ensáñase con el en tódalas súas intervencións. Vexamos unha mostra:

Señor don Gabriel, no le saberé decir con eusautitú... Quizásmente que aún no tendrá voltado, en atención a que no se ha visto por aquí su comparecencia ( $M N$ 256).

c) Finalmente, no nivel inferior é onde a galeguización do idioma é maior: o coñecemento do castelán é escaso ou nulo. O dominio da interferencia xa non se reduce ó léxico a morfoloxía, a sintaxe, incluso a fonoloxía de ámbalas linguas deixan de ter fronteiras, lanzándose a unha simbiose sen solución de continuidade.

Este proceso acentúase sobre todo nas situacións formais: conforme aumenta a clase social do interlocutor ou a solemnidade do encontro aumentan tamén os fenómenos de interferencia, como o da gueada, escasos noutras situacións.

A propia Pardo Bazán lembra algúns destes casos de contacto en crónicas periodísticas en que relata as impresións das súas viaxes por Galicia. Non sabemos 
como se expresaría aquela muller (duns sesenta e cinco anos, a Tradición) que lles levaba ós excursionistas ó castelo de Sobroso a cesta co xantar, pois dona Emilia ten coidado en traducir as tres lendas de mouros e encantos que a súa informante vencella ó castelo $0^{14}$, conservándolle soamente os imprescindibles termos localistas (rapaz, pucha...). Máis éxito temos na reproducción en estilo indirecto libre que se fai das anécdotas que conta aquel vello que topan cerca do semiderruído mosteiro de Ribas de Sil:

Y recordaba, ¡vaya si recordaba! el convento hecho una gloria de Dios, con sus veintidós novicios, sus cuatro Padres Maestros que enseñaban teologuía y todas las cencias, su cillerero (despensero) y el Padre nuestro (el abad)... (DMT 232).

Dona Emilia reproduce nas obras literarias estas situacións. Un dos contos máis significativos neste sentido é "Atavismos" (recollido en Cuentos de la tierra) os interlocutores son o crego de Gondás, unha descoñecida "señora condesa" (E. Pardo Bazán) e unha aldeá velliña. O crego, home letrado que rexeita as supersticións, pídelle a esta última que relate a desgracia que envolveu os seus dous fillos ("-A ver, muller, cuente su desgracia a la señora condesa que puede dar pasos para que se averigüe el paradero de su hijo...", CNT 376). No primeiro acercamento á vella o crego intenta expresarse na lingua desta:

-Buenas tardes, tía Antona... Pouse el feixe muller... Yo ayudo... (CNT 376).

Acadada a súa benevolencia, a vella exprésase libremente:

-Túvome envidia desde moza. Su mozo la dejó, y el rapaz se le murió de mal extraño. Y entremientras, mis dos fillos, mis dos rosas, dábanle enojo de se comere las manos. Según pasaba por delante de mi puerta, les echaba a mis palomiños unos mirares que acuchillaban. Y ellos [...] le tenían idea mala, a fuerza de la ver pasar mirando de aquel modo, que metía miedo... ¡Señor abad! ¡Por el alma de quien tiene en el otro mundo! Vusté bien sabe que mis hijiños eran honrados, que no hicieron en jamás acción mala de Dios... Tentóles el demo, que no los tentara si la bruja no los mirara así... ¡Fueron los ojos de la Guliana, señores benditos, fueron los ojos, y no fue otra cosa, que con un palo se los había yo de sacare! (CNT 377).

O texto non necesita máis comentario. É clara a condensación de galeguismos de todo tipo. Fixémonos só na gueada (Guliana). A gueada supón un intento errado por parte dun amplo sector de galego-falantes (os que non teñen acceso á cultura do poder) de se aproximaren á fonoloxía castelá, allea e difícil, sobre todo no que se refire á distribución do /g/ e do /x/, inexistente na lingua materna.

14 ....hí va la versión castellana de dos ó tres cuentos que la tradición afirmó como verdades de á puño (DT 215). 
O resto dos casos en que detectamos gueada son principalmente situacións deste tipo:

En Los pazos de Ulloa, Perucho, que acaba de rapta-la súa media irmá, pola cal sente devoción, para calmala e divertila, ponse a contarlle un conto. Tamén intentará falar na lingua, para el estraña, que cría que entendería mellor a nena (obsérvese a aclaración de Pardo Bazán "maíz quería decir Perucho") 15.

Una ves [...] era un rey muy malo, muy galopín, que se comía la gente y las presonas vivas... Este rey tenía una nené bunita, bunita, como la frol de Mayo... y pequeñita, pequeñita como un grano de millo (maíz quería decir Perucho). Y el malo bribón del rey quería comerla, porque era el coco, y tenía una cara más fea, más fea que la del diaño [...] Y había un pagarito sobre un árbole, y oyó al rey, y dijo, dice "Comer no la has de comer, coco feo." ¿Y va y qué hace el pagarito? [...] Y va el pagarito y con el bico le saca un ojo, y el rey queda chosco (PU 280).

Nalgunha das situacións en que aparece a gueada a situación é algo diferente: os interlocutores pertencen á mesma clase social pero áchanse diante dunha situación formal, solemne case. Vexamos algún exemplo. O primeiro deles prodúcese no enterro dun neno. A señora Antonia que "tenía a su cargo el pésame y la oratoria consoladora, por ser la más suelta de lengua y de mejor explicación entre todas las viejas de la parroquia" (CNT 48) exprésase así publicamente:

María Vicentiña, prenda de mi corazón [...] Echa cohetes, que hoy le envías a Nuestro Señor del Cielo divino un ánguele. Dios está alegre, Nuestra Señora está alegre, el bendito San Antón está que hasta pega gargalladas, y los demás anguelitos [...] Llega allá, a los cielos divinos tu neno, y lo reciben con violines, panderetas, conchas, gaita... ¡A fellas que oigo la música! (MO 789).

O segundo prodúcese nun camiño: un mozo agarda por un rival. Xa non se pode aprazar máis o enfrontamento. Só un sairá vivo. O que agarda, atravesándose no camiño, berra:

-¡Ey! ¡No se pasa! ¡Bagarse del caballo, que aquí está un amigo! (CNT 300).

A aparición da gueada noutros casos (entre membros da mesma clase en contextos non formais) é rara, pero interesante, e sempre obedece a unha xustificación verosímil: en Responsable (CNT 436-439) oímola en estilo indirecto libre de boca dun rapaz de once anos, de clase ínfima, fillo dunha viúva, Cirilo, a quen a súa nai deixou encargado dos irmáns pequenos:

\footnotetext{
15 Parecido é o contexto que se mostra en Morriña no seguinte episodio o protagonista é un cocheiro, Martín, emigrado a Madrid como tantos:

-Señorito, qué cuaselidá! -exclamó Martín al conocer a Rogelio-. Esta joven (el cochero pronunciaba joven con $g$ ) viene en busca de la casa del señorito... (MO 789).
} 
Después, precipitadamente volvió a entrar en la pobre casa; había oído llorar a una de las criaturas, Gustiña -Justa-, que era el mismo pecado, y de fijo habría hecho alguna maldad (CNT 437).

Agora ben, a narradora acláranos antes que Cirilo oíra falar que el era fillo dun señor (verdade: pero dun señorito seductor, froito dun encontro casual), noticia que o levaba a apartarse dos outros rapaces da aldea e a fantasear coa volta dun pai que o restituiría na súa verdadeira posición. É o caldo de cultivo da gueada: a súa lingua debe ser a dos señoritos, cos seus fonemas.

En Sin querer (CNT 296-300), a frase ponse xenericamente en boca dunhas vellas medrentas

...que a todo se persignan exclamando:

-Asús, Asús me valga, mi madre la Vírguene! (CNT 298).

Fixémonos agora na palabra afectada un termo relixioso que sen dúbida oían repetir ó crego, e trataban de reproducir en lugar do propio, Virxe.

\subsection{O mundo urbano}

A realidade sociocultural da cidade é moi diferente da rural. O exemplo prototípico é Marineda, a Marineda que retrata por exemplo en La Tribuna, coa súa aristocracia no barrio alto, unha florecente clase burguesa na zona da Pescadería, e nos arrabaldes a clase baixa. Enumeración incompleta porque aínda nos quedan por mencionar as aldeás e campesiños que acoden da periferia rural (os marxinados dos marxinados). O conflicto social e lingüístico de todos contra todos está servido, pero principalmente -ou así o retrata E. Pardo Bazán-entre as clases inferiores.

A aristocracia ou a burguesía, totalmente castelanizada (grande é a diferencia entre os Cuentos de Marineda e os que no apartado anterior manexamos), soamente acerca un termo galego ós seus labios en casos esporádicos, como nalgún diálogo condescendente coa xente do pobo, por exemplo o seguinte entre Baltasar e a futura cigarreira

-Y tú, ¿qué haces, señorita de Roséndez? -interrogó Baltasar. ¿Andar de calle en calle canturreando? Bonito oficio chica [...]

-¿Y qué quiere que haga? -replicó ella.

-Encajes como tu amiguita.

$-¡$ Ay! No me aprendieron.

-Pues, ¿qué te aprendieron, hija? ¿Coser? (T 87).

Pero nas clases baixas a situación varía: os que viven na cidade teñen espírito de caste, séntense superiores ós aldeáns, ós que desprezan pola súa 
rusticidade $^{16}$. Así, Chinto, o pobre rapaz de aldea que é levado de aprendiz á casa de Amparo, causa risa na mísera reunión pola súa fala:

Sirvió la mesa, escanció y fue la diversión de los comensales, por sus largas melenas $[\ldots]$ por su puro dialecto de las rías saladas, que provocaba la hilaridad de aquella urbana reunión El barbero, que era leído, escribido y muy redicho; la encajera, que la daba de fina, y la comadrona [...] Amparo ni le miró (T 90-91).

Aínda que por breve tempo ${ }^{17}$, os membros das clases baixas urbanas teñen acceso ós rudimentos da escola, á lectura da axitada prensa do XIX e, sobre todo, participan da vida cidadá, pódense mesturar nos paseos coa burguesía e coñece-lo seus usos.

Entre proletariado urbano e rural as discrepancias son completas: culturais, políticas (progresismo vs. tradición) e, como non, lingüísticas: os labregos aínda conservan a súa lingua materna ${ }^{18}$, non así os cidadáns, de aí as súas burlas á fala daqueles. Por tal motivo, as interferencias lingüísticas que se detectan nun ou noutro caso son distintas: nas mulleres urbanas (o protagonismo desta novela é feminino) predominan as deturpacións producidas en palabras procedentes do mundo xornalístico (libertá, espotismo, oficialidá, descentraizar), incluso se permiten vulgarismos propios dun castelán-falante pero descoñecidos no galego: así a perda do - $d$ - en apretao.

Entre as de procedencia rural ou entre as anciás (educadas nun marco socioeconómico moi diferente) as interferencias son maiores: afectan tamén a fonoloxía. A gueada, o seseo, que deixaramos no campo, entran na cidade da súa man, como se ve neste diálogo prototípico (E. Pardo Bazán estivo estudiando durante dous meses in situ as condicións de traballo e a lingua das cigarreiras):

El pretexto de las riñas era que las de Marineda mostraban asombrarse de que las campesinas, viniendo quizás de tres leguas de distancia, estuviesen allí cuando apenas asomaba el día, y hacían rechifla de tal diligencia.

- ¡Vaya que es madrugar de Dios, hijas!

${ }^{16}$ Como di dona Emilia:

La explotación del hombre por el hombre tomaba carácter despiadado y feroz, según suele acontecer cuando se ejerce de pobre a pobre (T 121).

17 Amparo había ido a la escuela en sus primeros años, años de relativa prosperidad para la familia, sucediéndole lo que a la mayor parte de las niñas pobres, que al poco tiempo se cansan sus padres de enviarlas y ellas de asistir, y se quedan sin más aprendiza je que la lectura, cuando son listas, y unos rudimentos de escritura ( $T$ 69-70).

18 [Chinto] lloraba como un becerro, alzando en su dialecto el grito primitivo, el grito de los grandes dolores de la infancia [...]:

-¡Madre mía, madre mía! ( $T$ 161). 
$-¿$ Venidas a caballo del sol?

-¡Andar, lamponas! ¡Dejáis la cama por hacer y el chiquillo por mamar! ¡Madrastras!

-¡Ni os peinades tan siquiera!... ¡Andáis arañando en el pelo con los dedos por llegar seis minutos antes, ansiosas de Judas!

- ¡Tú dormiste en el camino, avariciosa! [...] Tanto madrugar, y tanto madrugar, y luego no hacedes ni medio cigarro en to el día, que mismo no sabedes menear los dedos, que mismos los tenedes que parecen chorizos, que mismo Dios os hizo torponas, que mismo...

Aquí ya la sorna y flema de las interpeladas tocaba a su fin, y respondieron coléricas, pero entre dientes:

- ¿Y luego? Cada uno se vale como puede, y vusté tendrá otras rentas, y más otros señoríos..., y ganarálo de otra manera diferente, y Dios sabe cómo será..., que yo no lo sé ganar sino trabajando, higa (T 127).

Obsérvese que as interferencias afectan por igual os dous mundos, pero só no rural aparece o estigma da gueada (contraposición hi jas / higa).

Dixemos con anterioridade que o galego representaba a nai e a natureza. Estas son as funcións que asume na súa obra literaria tamén. Como nai, é doce, agarimosa... Relémbrao Pardo Bazán constantemente:

[...] ella misma lo ató al cuello del forastero, diciendo mimosamente, con suavidad del todo galiciana:

-¿Queda así a gustiño, señor?

Don Gabriel agradeció sonriendo. El diminutivo, el calor de la seda [...] le produjeron el efecto de una caricia del país natal, adonde volvía por vez primera después de una ausencia muy prolongada ( $M N$ 67).

El rapaz se sentó sin soltar a la nena, diciéndole mil chuscadas y zalamerías a fin de acallarla, abusando del diminutivo que tan cariñosa gracia adquiere en labios del aldeano:

-Reiniña, mona, ruliña, calla, calla, que te he de dar cosas bunitas [...] ¡Calla, soliño, paloma blanca, rosita! ( $P U$ 277).

Y, exagerado por la emoción el acento cantarín y mimoso de la tierra, gritó... ( $Q$ 141).

-Dalinda me llamo, señor -murmuró ella, con el acento cantarín de la comarca (CNT 62).

Oyó la fresca voz de Casildita del Pazo, que le decía con el arrastrado y mimoso acento del país... (CNT 167).

Pero tamén é a natureza, a forza do campo e do seu mundo, fronte á cultura ou pseudocultura urbana. Esta idea móstrase inequivocamente no seu estudio sobre el 
Cancionero popular gallego de Pérez Ballesteros ${ }^{19}$. Co ímpeto todo da natureza xorde esta hedra galega que cobre co seu verdor o valado castelán que dona Emilia levanta no seu amplo corpus narrativo. Vexamos cales son os principais procedementos empregados para acadar este fin:

\subsection{O léxico}

É o procedemento máis doado para dar cor local. O número de palabras galegas que dona Emilia emprega é considerable, supera con moito o pequeno vocabulario de 40 palabras con que acompañou a súa edición de Historias y cuentos de Galicia. Ó final deste traballo pódese examinar o medio milleiro de palabras propiamente galegas que documentamos na producción pardobazaniana (apéndice establecido con criterio estricto, pois non entran en consideración topónimos, antropónimos, castrapismos, calcos semánticos ou palabras compartidos polas dúas linguas, co que a cantidade aumentaría considerablemente).

Case tódolos personaxes de dona Emilia utilizan nalgunha ocasión estes galeguismos porque, como dixemos, o acoso dunha lingua soe empezar por esta parte da gramática. Deste xeito, nomes de plantas e animais, utensilios domésticos, roupa, labores do campo, adxectivos coloristas, verbos, interxeccións, etc.:

Cuando los del rueiro se dieron cuenta del peligro, ardían ya dos o tres casuchas como yesca (CNT 400).

-¿Quiérese ir contigo ese peine? ¡Ya lo sabía yo, muller! Le voy a esganar hoy mismo (CNT 429).

Llégate a la artesa, mi hombre... Te voy a echar el caldo en la cunca. Mira cómo resciende (CNT 92).

Un «mantelo» tosco cubría la mutilación de las despedazadas y puras entrañas (CNT 147).

...una libra de pan reseso (CNT 39).

Unha boa cantidade das palabras empregadas por Pardo Bazán para dar color local son comúns co castelán. Agora ben, nesta lingua teñen un emprego tan limitado (son arcaísmos ou termos locais identificados no diccionario académico como asturianos, cántabros, leoneses) que propiamente poderían considerarse galeguismos con respecto ó castelán estándar e como tales os considera dona Emilia pois con frecuencia os marca en letra cursiva ou mediante outros

${ }^{19}$ Los elementos, las nociones primeras del arte, lo mismo que de la filosofía y de la ciencia, están en el pueblo, entendiendo por pueblo sobre todo la gente campesina, próxima a la naturaleza reveladora, en quien no ha ejercido su efecto desastroso y desflorador la media cultura, la instrucción barata, la lectura de periódicos y las ideas y los raciocionios manoseados de café, teatrillo, casino y figón (DT 119). 
procedementos (incluso inclúe algunhas no seu vocabulario do que antes falamos raposo, tojo, virar). É evidente que vallado é palabra castelá pero Pardo Bazán utilízaa cunha frecuencia e nuns contextos nos que claramente se percibe unha transcrición do galego valado:

-Mala hierba nunca muere -gruñó Nordés-, y esa casta de la fábrica dura más que las silvas en los vallados... (CNT 493).

A lista de palabras desta natureza é longa. Mencionaremos soamente as que nos parecen máis claramente caracterizadas como galegas: apañar, billarda, can, cancela, capón, conversa, de contado, demonche, gorja, mallo, mozo, moyo, pasmón, pega, peso, rapaz, rapaza, raposo, rematar, sachar, saltón, serenar, tanque, topar, virar, etc ${ }^{20}$.

A utilización de termos locais é tan abundante que inzan incluso os períodos propios do narrador omnisciente. Dona Emilia preocúpase para que en toda serie apareza unha palabra galega, sexa cal sexa, se aquí é vieiteiro alí pode ser fiúncho e non importa que aquel vieiteiro se converta agora en saúco:

...respirando el olor fecundo, penetrante, que derraman los blancos ramilletes de vieiteiro... (CNT 55).

En la iglesia románica [...] flotaba la fragancia de la espadaña, fiuncho y saúco en flor... (CNT 321).

Cumprido o propósito, o resto das palabras xa non parecen interesar (por esta razón dáse unha grande cantidade de variación interlingüística ${ }^{21}$ : tojo alterna con aliaga,

20 Ás veces, hai unha frase feita común: "Gabriel no quiso oír más y desapareció como un rehilete, en dirección de la era" ( $M N$ 257). A frase feita para ponderar a velocidade, correr coma un riguilete, documentámola en AO e en falantes de Valencia do Sil.

Evidentemente, o estado de lingua que se debe ter en conta é o de finais do século XIX e principios do XX. Así, pode chamar a atención que dona Emilia marque con comiñas berberechos en "Los juguetes de la niña fueron «navajas», almejas, «berberechos»" (CNT 200). A explicación topámola en que, polo que se refire ó castelán, a forma aparece por primeira vez no diccionario académico en 1884 , como propia aínda de Galicia.

21 Dona Emilia é consciente da importancia que ten a palabra. Unha palabra vale máis que mil descricións, poderiamos dicir contrafacendo o coñecido dito. Por iso, descricións magníficas como a seguinte non poden rematar sen que se mencione a unidade léxica denominadora:

Para subir a los Castros había que de jar a un lado el monte y el encinar, torcer a la izquierda y penetrar en uno de esos caminos hondos, característicos de Galicia, sepultados entre dos heredades altas y cubiertos por el pabellón de maleza que crece en sus bordes: caminos generalmente difíciles, porque la llanta del carro los surca de profundas zanjas, de indelebles arrugas; porque a ellos ha arrojado el labrador todos los guijarros con que la reja del arado o la pala tropezó en las heredades limítrofes; porque allí se detiene y se encharca el agua y se forma el barro; los peores caminos del mundo, en suma, y sin embargo, encantadores, poéticos, abrigados en inviernos, porque almacenan el calor solar, y protegidos del calor en verano por la sombra de las plantas que se cruzan, cerrándolos como tupido mosquitero; encantadores, porque están llenos de blancuras verdosas de saúco, palideces rosadas de 
aulaga, escajo ou árgoma -de todos estes xeitos se denomina no diccionario da Real Academia Española o Ulex Europaeus-, cancela con cancilla, deshoja con desfolla, sella con herrada, chícharos con guisantes, borona con brona, etc., sempre en boca do narrador):

[La vieja] enseñó orgullosamente un magnífico pan, una soberbia torta de brona (CNT 162).

Así podían disponer [...] de la miaja de leche y la borona migada del desayuno (CNT 491).

A actuación da autora neste sentido é variada. En ocasións o termo aparece illado, sen traducción, ás veces nin sequera identificado polas comiñas ou cursivas que nos advirten da licencia:

Cuando Dalinda volvió presentando una olla de castañas cocidas, echando vaho caliente, tapada con un trapo y recendiendo a anís... (CNT 63).

El aire diáfano [...] empezaba a impregnarse de olores ligeros que exhalaban los mojados pinos. Una pega, manchada de negro y blanco, saltó casi a los pies del caballo... (CNT 147).

Noutras ocasións, polo contrario, o termo aparece acompañado da correspondente traducción castelá (mediante unha explicación apositiva, parénteses, coordinación disxuntiva, alusións explícitas a que na terra se denomina dese xeito, etc.). Dona Emilia comprácese na función metalingüística:

En la aldea la llamaban roxa, pero en sentido de rubia, pues tenía el pelo del color del cerro que a veces hilaba (CNT 126).

Sentadas en tallos -asientos de tronco de roble bruto, como los que usan los labriegos más pobres-, dos viejas secas... (PU 147).

También la iluminaban los hilos de brasa de unos tallos o troncos menudos que ardían en el hogar (CNT 162).

...las medas o altos montículos de mies remedaban las tiendas de un campamento (MN 38).

Una escalera de madera conducía al sobrado o cuarto alto ( $M N 18)$.

...Y el leito o camarote de tablas en que dormía el matrimonio ( $M N 18)$

Hacia la derecha, el corral estaba limitado por un alpendre o cobertizo (CNT 487).

flor de zarza, elegancias airosas de digital, enredadas cabelleras de madreselva que vierten fragancia, cuentas de coral de fresilla, negruras apetitosas de mora madura, plumas finas de helecho, revoloteos y píos y caricias de pájaros, serpenteos perezosos de orugas, escapes de lagartos, contradanzas de mariposas, encajes de telarañas sujetos con broches de rocío y desmelenaduras fantásticas de rojas barbas de capuchino, que allí, colgadas entre zarzas y matorrales, parecen ex votos de faunos que inmolaron su pelaje rudo al capricho de una ninfa. Y aquel camino en que penetró la pareja montañesa añadía a estos méritos, comunes a todas las corredoiras, un misterio especial... (MN201-202). 
La frieira, la gran cueva a la sombra del enorme peñasco, en que la sabrosa trucha busca la capa de agua densa y no escandecida por el sol (MN 188).

...caía sobre un ribazo todo estrellado de flores monteses, donde crecía el tojo o escajo tan nuevo y tierno que sus pinchos no lastimaban ( $M N 193)$.

Un cazador furtivo, escopeta negra infalible, conocido en el país por el alias de Bico de Rato (hocico de ratón) (PU 198).

Barbacana recibiría su pago en una corredoira (camino hondo) (PU 222).

A ella la conocen todos por Bocarrachada (Bocarrota) (CNT 112).

Dos onzas no podían hallarse sino en la boeta o cepillo de Santa Minia (CNT 133).

Hizo el padre el cumplido panegírico de su Ciprián o Cibrao, que así le llamaba [...] Cibrao, amoroso como una rula (tórtola) (CNT 176).

Le disparó un croyo, una piedra perlada y lisa, con filo (CNT 393).

Martín el Trenco, llamado así a causa de sus estevadas piernas (CNT 419).

La trucha, que abunda en el río Amega, suele refugiarse sibaríticamente, durante la canícula, en ciertas hondanadas o pozos profundos llamados en el país frieiras (CNT 263).

Y sobre el pecho refulgirá la patena, conocida por "sapo" (CNT 274).

Fresas rojas diminutas, llamadas amores (CNT 347).

Subir a hombros los culeiros o cestones por las cuestas casi verticales de las laderas $(C N T 459)^{22}$.

Unha faceta á que dedica dona Emilia especial atención é a do nome propio. A elección de antropónimos e topónimos é coidada. Polas súas páxinas aparecen nomes de ríos ou lugares que poden corresponder con outros existentes, pero o normal é que a autora cree termos aproveitando o material que a nosa realidade lingüística lle ofrece: ós coñecidos Marineda, Estela, Vilamorta, Areal, Auriabella e outros xa mencionados pódense engadir centos tan sonoros como Cebre (Cea), Bertial, Boán, Bonsende, Bouzas, Castrodorna, Doas, Dosiñas, Eiguirey, Espadanela, Gondás Gondelle, La Illosa, Lameiroa, Limioso, Loiro, Los Carballos, Lubrego, Magonde, Migoeiro, Montiño, Mosteiro, Paramelle, Penamoura, Proenza, Ramela, Rapela, Resende, Río Amega, Sabuñedo, Sainís, Sandiás, Seigonde, Tornelos, Treselle, Valdelor, Valeiro, Vilar, Xabreñes, e tantos outros. Nalgúns casos o coñecemento da xeografía descrita permítenos reconstruír o seu xeito de proceder En Siglo XIII menciónanse os seguintes lugares:

\footnotetext{
22 Normalmente é o termo castelán o que especifica ó galego, pero nalgunha ocasión sucede o contrario: Y así estaba ahora, que parecía un Antruejo (Antroido) (MN 164).

En los sitios de más sombra y humedad las perfumadas fresillas o amores abundan (MN203).

A la caída de la tarde se le había visto en el playazo jugando a las guijas o pelouros (CNT 463).
} 
Ahí, en el mismo lugar de Miñobre...Según se baja para la carretera de Areal, a la orilla del mar... Antes del molino de Breame (CNT 110).

Sabendo que Areal se corresponde con Sada, Miñobre e Breame están formados sobre os lugares próximos de Miño e Bréamo.

A elección dos nomes de persoa non presenta menor variedade: Adrián, el tío Amaro, Alberte, Caliste, Camila de Berte, Catuxa, Cibrao, Culás de Bonsende, Dominga de Alfónsiga, el viejo Avelaneira, el tío Miñobre, Ermitas Valdelor, Gorio Nogueiras, Goros, Ildara, Jácome, Juaniño de Rozas, Leliña, Lobeiro, los Landrey, Margarida de Leite, Marica de Sanguiño, Marina, Minia, Pepe de Reigal, Vieira e tantos outros. Interesantes son especialmente os alcumes que a escritora crea para caracteriza-los seus personaxes: Bico de Rato, Bocarrachada; Diaño, el Caldelo; el Codelo, el Miñoca, el Corvo, el tío Matabois, Finafrol, Langrán, Lebriña, Madrugueiro, Mansegura, Margarida de Leite, María la Fiandeira, Mariana la Chosca, Pedro Miñato, Pedro de Furoca, alias el Grilo, etc. Na formación de hipocorísticos, o galego e o castelán discrepan radicalmente: o primeiro mantén a parte final da palabra, o castelán a inicial (así, Gumersindo dará Gumer ou Sindo segundo a lingua). Dona Emilia dá cumprida conta deste feito Sabel, Selmo, Selme, Sendiño, Sidoriña, Berte.

Por outra banda, dona Emilia coñece, e utiliza, o costume aínda vivo de nomear co nome da parroquia ó seu párroco:

-Aguárdate un poco, Naya -le di jo familiarmente, dándole, según costumbre de los curas, el nombre de su parroquia ( $P U$ 236).

-¡Eh..., Boán! Que con mucho disimulo me estás echando abajo la gracia... (PU 59).

En toda su vida supo Lubrego por dónde se agarra una escopeta (CNT 164).

-Eso es cierto -confirmó Gondás, dando vivas chupadas al pitillo (CNT 377).

Como é de esperar, na fala dos personaxes o uso de galeguismos adquire especial importancia como marca de nivel social. Naturalmente, o uso é inversamente proporcional á clase sociocultural dos personaxes, ata chegar ós de ínfima condición, en que non son raros procesos de interferencia lingüística máis acusados como o do calco semántico (emprego de palabras castelás co significado da galega correspondente) e castrapismos (palabras mestura de galego e castelán):

Entre os calcos semánticos merecen especial atención os modismos e frases feitas que con frecuencia son traduccións literais das correspondentes galegas. Así, en $L a$ madre naturaleza reproduce en estilo indirecto a fala da Sabia: "no le secase la vaquiña, que de esta hecha se le moría"; a frase é dificilmente intelixible se non se acode á locución adverbial galega desta feita 'desta vez'. Vexamos algúns casos 
máis, coa mención previa da forma orixinal galega: fóra á alma (Fras. $n^{\circ} 4573$ 'dise cando se lle chama animal a unha persoa'): "[...] hablando del bocio de la vieja, y comprometiéndose a extirpárselo con tanta prontidud como el tumor de la vaca, fuera el alma" (MN 24); lobos te coman (Fras. $\mathrm{n}^{\circ}$ 1040): “ ¡Comida de lobos vea yo a esa vieja!" (PL 55); traballar como unha loba: "la gallega trabaja, según la frase del país, «como una loba»" (CNT 273); Non dar a pé nin a perna (Fras. n 1502, 'non se mover'): "Dejé a uno, que ni da a pie ni a pierna" (CNT 95, 36); Poucas han ser as malas fadas (Carré 'poco hay que esperar, poco falta'): "Pocas son las malas fadas al fin mañana nos vamos..." (MO 897); un bocadiño "-¿Cómo cuanto faltará? [...] -Un bocadito, un bocadito (PU 9); a carreiriña dun can: “-¿Y falta mucho? [...] -La carrerita de un can..." (PU 10); fillos nacidos por detrás da igrexa:"Esos hijos así, nacidos por detrás de la iglesia" (PU 64); unha man de: “¿Qué mano de cuartos, mi madre!” (CNT 59), "En Madrid hay una mano de pillería" (CNT 312); dar noxo: "Larga de aquí, y cálzate esos pies, que das enojo" (CNT 453); o arco da vella: “ ¡El arco de la Vieja!” (MN 13); can de palleiro: "Perro [...] de pajar" ( $M N 18)$; vai boa que: "Va buena que dormirán" (MN 35); de a cabalo: "Viene de a caballo" (MN 282); meter medo: "mirando de aquel modo, que metía miedo" (CNT 377); molla-la palabra (Glos. "echar un trago'): "los majadores tenemos que mojar la palabra" (MN 227); montes e moreas (Fras. ${ }^{\circ}$ 4211, ER, locución común segundo o DRAG): “¡Y que traía un capitalazo, montes y morenas!" (CNT 258); se cadra: "ellos se hermanan con el boticario, recetan y recetan, cobran la mitad, si cuadra..." (CNT 44), "Sus boenas camas compridas, con sus seis colchones para la blandura, si cuadra" (CNT 503); a modiño: "Mira, así... a modito" (T 92, 205); ;e mais si! ('es verdad' en Carré): "Quedóse don Mariano hecho estatua. ¡Y más sí! Allí había vivido el canónigo Lamela, y existían cartas de él a su hermano, un fajo, en el archivo!" (CNT 457); miña xoia: "No, señor, mi joya” (CNT 405), pero “-A ti, no miña xoya...” (CNT 468), etc.

Pero con frecuencia é só unha palabra a traducida literalmente: roxa 'rubia': "Aquella noche, la roja Sabel [...] notó algo extraño en aquella actitud de su marido” (CNT 92); soidade: “¡Ay riquiño, qué soledades tenía de mí” (CNT 199); home 'esposo': "Mi hombre, la cena está lista” (CNT 92), “¿Y qué dirá mi hombre cuando sepa que dejo la casa y los rapaces?" (CNT 310); cumprir: "Mañana cumple madrugar" (CNT 94), "Aquella tarde «cumplía» ver al cura de Burón” (CNT 154); gramalleira: "Sobre la losa del hogar pende de la férrea cremallera el negro pote" (CNT 273); acordar: 'lembrar' "Yo acuerdo al fransés" (CNT 492); disca: "Dice que ninguna persona humana ha entrado en la trasbotica (CNT 139), "Dice que al señor abad de Lubrego le robaron barbaridá de cuartos" (CNT 163); seica: “¿Seque no diferencia las verdes de las maduras? (MN 142); velaí: “¡Vela allí!” (MN 119), “`Velo, ahí viene!” (PU 277); logo "pronto”: "La señora no vos hace nada, porque luego ha de espichar. ¿No le veis estampada en la cara la muerte?" (CNT 77); novo: “¡Tan nuevo! ¡Tan mociño y tan galán! (Q 530); ¡coiro!: ¡Ve a 
dormir la mona, cuero! ( $P U$ 254); repoñerse ('volverse hacia uno con amenaza' en $E R)$ : "-Yo que quiere que haga... No me voy a reponer contra mi señor padre" $(P U$ 29); forcado: "Con sus horcados iban las mozas formando las medas" ( $Q 529)$, etc.

O que denominamos castrapismos (palabras mestura de galego e castelán) poden ser de varios tipos, desde a creación dunha palabra mixta (tipo dazaocho) ata a galeguización (aunar a partir de ayunar) ou castelanización (deshoja formado sobre desfolla) de palabras da outra lingua: "Ya sabrás que sólo me diste dazaocho reales" (CNT 48); "De Areal aquí hay la carreriña de un can” (CNT 48); “¿Y los bueis?" (CNT 59); "Era [...] muy llano y muy habladero" (CNT 61); "Apriesa" (CNT 81); "El auntamiento" (CNT 93); “Allá ellos que se «auden» (CNT 198); “De moza soltera, rojiña” (CNT 139), “Y si llora la joyiña de Dios?” (198); "Camino de fierro", (CNT 97); "la boena vida se da" (CNT 367); "remeje que te remejerá" ( $M N 45)$; “se echará de pierda” (MN 173) (botar de perda, 'abortar' en Gl.); maja ( $M N 161)$, majar ( $M N 225)$, majador ( $M N$ 227) pero mallador ( $M N$ 227 ) e mallar ( $P U$ 254); llorimiquear ( $M N 195)$; carero ( $D T$ 277); en jamás $(M N$ 184); "había un rebumbio de dos mil júncaras" (MN 293) (Xuncras 'Xudas'); “y entramientras, mis dos fillos, mis dos rosas, dábanle enojo" (CNT 377), etc., a que nin sequera escapa a autora cos seus tojos, lages, carreros ou trasacuerdos:

Mientras recorrían la senda demasiado estrecha, de resbaladizas laxes pasaba el brazo alrededor de un talle delicado (CNT 462).

Avanza despaciosamente por el carrero angosto que serpea entre viñedos y matorrales (PU 287).

Iba pesaroso y cabizbajo, porque ahora le venía el trasacuerdo de que no había preguntado... (MN 111).

La concienzuda actividad con que los gallegos ponemos en planta lo que se conoce por trasacuerdo" (PL 15).

Entre os personaxes de escasa formación tampouco escasean hiperenxebrismos e vulgarismos. Se ben é difícil determinar que se entende por vulgarismo nunha etapa da lingua en que non hai ou se está formando a norma común, non cabe dúbida de que formacións como as que agora citaremos son utilizadas con tal fin por dona Emilia: custión (MN 28), curazón (CNT 461), indinado (MN 278), faucioso ( $P U$ 250), vusté (MN 30), enfermedá (CNT 378), voluntá ( $P U$ 378), mocidá (CNT 474), tranquilidá (CNT 490), etc. Sobre estas palabras voltaremos a falar no apartado dedicado á fonoloxía.

Non quixeramos rematar este apartado sen mencionar unha cuestión importante: dona Emilia parte sobre todo do seu coñecemento directo da lingua galega. Sabemos perfectamente que ela gustaba de ler e recitar composicións poéticas en galego (incluso en catalán), pero sobre deste fondo libresco imponse a observación 
da fala viva. Como consecuencia deste feito, algunhas palabras carecen doutra documentación fóra da súa obra (o que non é fraco servicio á nosa lexicografía) ou menciónanse con significados distintos dos que usualmente lles asignan os nosos diccionarios: a palabra carrizo non a documentamos na acepción de 'folla do piñeiro' (DMT 214); a garduña (DMT 220-222) figura en case tódolos diccionarios como nome dun mamífero, non dunha ave; o mesmo sucede con panela ('patela' e non 'tixola' na súa obra), etc.

Mencionemos tres palabras sen máis documentación: trova, esgarrichar, nuricha. Da primeira di M. Mayoral:

Todavía es peor el caso de «trova», que aparece tres veces en la novela, sin que pueda saberse a qué se refiere. Dos veces aparece referida al marqués del Solar de Fierro «[...] con su plateada trova enrollada alrededor de un rostro oval, sereno...» Al final de la novela evoca Minia la figura del marqués «con su romántica trova». Y en la descripción del retrato de Wiertz encontramos de nuevo la palabra «tenía una figura romántica, con trova» $(Q 86)$.

Dúas veces máis, que nós saibamos ${ }^{23}$, utiliza este termo, que non aparece nos diccionarios pero que aínda está viva na fala dos coruñeses co significado de 'pelo longo', 'guedellas', aplicado, polo que parece, só ós homes.

Esgarrichar tampouco figura nos diccionarios, pero si unha serie de variantes (esjurrichar en Mir, esgurruchar en Rd e Cuv, escorrichar en Pon), o significado das cales ('aproveita-las últimas gotas dun líquido') nos cadra perfectamente ${ }^{24}$ :

-¿Quién es el hijo de can que me ha esgarrichado la caña? (CNT 488).

Nurichas, polo contexto en que que se emprega ("Recogía mariscada, cangrejos, mejillones, lapas, nurichas, almejones y vendía...", CNT 339) alude necesariamente a algún pequeno animal mariño. Varias persoas relacionadas co mar supoñen que se refire ás 'minchas', suposición verosímil se pensamos que o sufixo da nosa palabra casa ben co tamaño da mincha. Esta posibilidade fainos pensar que se trate dunha errata xustamente por mincha, producto dunha mala lectura (no mesmo conto, El pañuelo, de dúas escasas páxinas, lese tamén “poje o cesto ligeramente convexo" (CNT 339), sen dúbida errata por paje, é dicir, paxe). Téñase en conta que nun manuscrito nuri- e min-son practicamente imposibles de diferenciar.

\footnotetext{
23 Tal vez nace mi ilusión de la recortada melena que cae recta sobre el entrecejo y se ahueca abajo formando trova, peinado característico que hoy se conoce con el nombre de pelo á lo Villamediana (DMT 254).

...un ciego se mantenía inmóvil, muerta la cara, mal af eitadas las barbas que le azuleaban las mejillas, lacio y en trova el grasiento pelo ( $T$ 98).

Marina Mayoral nas notas 186 e 326 de $Q$ interpreta 'barba'.

24 A raíz da nosa palabra explícase por cruzamento con gar- de garganta, gárgara, esgarro, etc.
} 


\subsection{A gramática}

Maior asombro que o dominio do léxico galego nos produce o da gramática. Tódolos trazos caracterizadores do galego fronte ó castelán aparecen na súa obra, mesmo os que son difíciles de topar nas gramáticas da época e nas da nosa, como axiña veremos.

\section{a) Morfoloxía}

No campo morfolóxico, próximo estructuralmente ó do léxico, prodúcense os mesmos fenómenos que neste. Así, por exemplo, topamos adverbios, pronomes, preposicións ou locucións equivalentes: hastra (CNT 199), perto (CC 152), pra (CNT 461), non (CNT 179), vós (CNT 97), vos (CNT 72), ninguén (CNT 290), a min (CNT 475), a carón de (CNT 520) ou formas verbais con desinencias ou radicais galegos

-Parecéis parvos. Os pasmáis de lo menos. ¡Como nunca asomástedes el nariz fuera de este rincón del mundo! ¡Si hubiésedes cruzado a la otra banda del mar, allí sí que encontraríades invenciones (CNT 96).

-¡Válgame Dios, hom! ¡Qué terco es! [2ª persoa de singular] (CNT 457).

Normalmente, as formas preferidas por dona Emilia son as propias do que podemos chamar galego común: Todos habemos de morir ( $M N$ 24), valerá ( $M N$ 28), queredes (CNT 198), abride (CNT 247), morrín (CNT 297), haberá (CNT 314), ¡Asús me valla! (CNT 376), ;así caya un rayo y me abrase! (CNT 376), vay (imperativo, CNT 415), (ti) es (CNT 457), rite, rite (CNT 49), veredes (CNT 473), poderá (CNT 521). Pero con relativa frecuencia tamén aparecen formas dialectais, de distribución máis reducidas: imperativos day (MN 227), ¡Teney vergiienza! ¡Soltay los cuartos! (CNT 67), propios do leste e sur de Galicia; formas de segunda persoa do plural como asomástedes (CNT 96), vístedes (CNT 97), que se dan, por exemplo, na ría de Arousa. Tampouco poden faltar os castrapismos de que falamos no apartado anterior: estive (MN 293), iA ver si vos callades, eia! (CNT 461), tenedes (CNT 461), etc.

Na morfoloxía nominal tamén se documenta algún dialectalismo, pero en número menor, por exemplo a utilización da forma -án para o feminino:-¿Ahora me gastas medias, como la hirmán del abade? (CNT 289). Tamén encontramos algún castrapismo como no plural bueis xa mencionado. Neste sentido, polo que respecta ó xénero dos substantivos, en caso de discrepancia entre o galego e o castelán, dona Emilia prefire utiliza-las formas galegas, caracterizadoras da terra, dando lugar e expresións híbridas como la puente ${ }^{25}$, el nariz (CNT 96), un costumbre (un costumbre de cuando ganaba mi vida con la sardina... CNT 494).

25 En castelán puente ten xénero ambiguo, pero, segundo o diccionario académico, o feminino é antigo ou rexional. 
Sen dúbida, o risco máis caracterizador da morfoloxía nominal móstrase na utilización do diminutivo. O emprego do diminutivo -é un tópico, un tópico que incluso acepta dona Emilia- comunmente considérase como un trazo propio da nosa fala:

El rapaz se sentó sin soltar a la nena, diciéndole mil chuscadas y zalamerías a fin de acallarla, abusando del diminutivo que tan cariñosa gracia adquiere en labios del aldeano:

-Reiniña, mona, ruliña, calla, calla, que te he de dar cosas bunitas [...] ¡Calla, soliño, paloma blanca, rosita! ( $P U$ 277).

$\mathrm{O}$ valor que adquire a forma diminutiva pode ser moi variado, como ben saben os estudiosos do tema:

- O cariño entre noivos (Perucho, Peruchón, Rita, Ritona chámanse o marqués de Ulloa e a súa prima Rita cando parecía que ela ía ser a escolleita como esposa; e os seus namorados fillos, antes de se saberen irmáns, utilizan expresións do mesmo tipo: tontiña (MN 8, 184), brutiño (MN 34), vidiña (MN 194, 198), queridiño ( $M N$ $198)$, ruliña $(M N 198)$ ou cos fillos ${ }^{26}$ e seres queridos, sexan persoas, animais ou cousas. Vexamos como se dirixe a Finafrol, a pobre nena, dona Gregoria, que coñece as súas virtudes: - ¡A ver, rosiña de mayo! (CNT 495); Yo te lavaré la otra, palomiña (CNT 497); ¿Me entiendes, froliña? (CNT 497). Máis exemplos:

Desde que se le había muerto su difuntiño, no podía dormir sino allí, porque tenía miedo en el antiguo leito (MN 162).

Durmió como un santiño, y ya anda corriendo por la huerta (PU 29).

-¿Dónde se duerme hoy, Sidoriña? (CNT 109).

¡Cómo branqueas, Mariniña! (CNT 182).

Venir un día de viento ... y iplan!... ¡adiós casiña! (CNT 176).

- Conmiseración, lástima:

Y su biografía, exclamada entre compasivos gemires de las comadres, era la de una malpocada, sin familiña, venida nadie sabía de qué tierras (CNT 322).

- Porén, con frecuencia, o diminutivo non oculta a clara intención irónica, de interese ou falsa humildade:

-Oyes, tú, Juan Ramón... El clérigo sí que tendrá a rabiar lo que aquí nos falta... Ricas onciñas tendrá el clérigo (CNT 133).

${ }^{26}$ É ben sabido que os apelativos diminutivos dedicados ós nenos pódense manter moito máis da infancia: "Es vuestro hermano, mi señor primo, el mayorazgo De la Lage, Gabrieliño", di o marqués ( $P U$ 89) diante da foto dun mozo de dezasete anos vestido co uniforme da Academia de Artillería; don Camiliño chama a nai da Camarona ó seu futuro xenro, o fillo maior -en idade casadeira- da dona da fábrica de conservas (CNT 202). 
De pronto, un cambio súbito demostró en el tío Amaro esas facultades de histrión que llegan a poseer los mendigos al cabo de cierto tiempo de ejercer su profesión intranquila y perseguida. Adoptó aire humilde, y murmuró, seguro de que Finafrol no le desmentiría:

-No la robé, no, señoritiños, que alhajas con dientes no tienen para qué las robar los pobres (CNT 503).

-Y vamos, señora Antona, que encontraron cosas sabrosillas, ¿eh? La Juliana, en tantos años de vivir como un sapo en su agujero, tenía arañados unos cuartitos, y los guardaba en el pico del arca; además sus hijos de usted cargaron con dos ferradiños de maíz, y unas buenas costillas de cerdo, y dos ollas de grasa, y unas pocas de habas, y un pañuelo nuevo, amarillo... (CNT 378) [di o cura de Gondás á nai dos mozos desgraciados que roubaron á Guliana porque -dicían- lles tiña envexa].

Y como el novio no podía, iqué había de poder, malpocadiño!, subir por su pie la escarpada cuesta que conduce al Plomo [...] se discurrió que dos fornidos mocetones de Gondelle [...] llevasen a don Fortunato a la silla de la reina hasta el templo (CNT 100) [Convén dicir que don Fortunato ten setenta e sete anos e medio e sobe ó santuario para casar con Inesiña, de quince anos e dous meses].

Como noutros casos tamén aquí topamos formacións híbridas: palomiña (CNT 497), rojiña (CNT 139), joyiña (CNT 198).

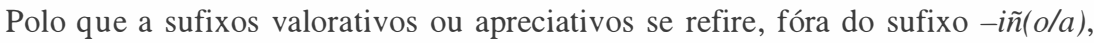
extraordinariamente dominante, topamos as formacións pequerrucho e pobretalla (formado sobre o modelo de xentalla):

Aquí lograré yo averiguar quién fue la grandísima perra que soltó a este pequerrucho cerca del arroyo (CNT 399).

Los domingos, toda la pobretalla de los antiguos compañeros de Finafrol se descolgaba a la puerta del corralón (CNT 525).

\section{b) Sintaxe}

Polo que respecta a fenómenos máis relacionados coa sintaxe, dona Emilia bota man con destras pinceladas daqueles trazos diferenciadores que máis claramente caracterizan o galego con respecto ó castelán:

Na utilización das formas verbais, como os antepretéritos en -ra (No dijeron que muriera, CNT 493), futuros de subxuntivo (mientras mi padre viviere, aquí aquí me ha de sostener la tierra, CNT 306), períodos condicionais do tipo "Ahora se me murió mi tío [...], que si viviera él, no sirviera yo más que a Dios” (CNT 62), "tentóles el demo, que no los tentara si la bruja no los mirara así (CNT 377), construcción de ende mais xerundio (ende tornando yo contigo, CNT 59), etc. 
O mesmo acontece coa elección de perífrases ter máis participio ("Ya tenemos ido más lejos", $M N$ 181; "hasta te tengo peinado mil veces", $M N$ 190; “¿No me lo tenedes contado vosotros mismos millenta veces", CNT 493; "por estos montes no debe de los haber, que si no, ya los tendría matados", PU 203), haber máis infinitivo ("ropa ha sobrarte", $C N T$ 311; "no me pidieron consejo, que yo bueno se lo había dar", CNT 377; "tampoco me ha curar", CNT 378), estar a máis infinitivo ("estando yo a cortar la hierba", $C N T$ 450), ir máis infinitivo ("vamos hablar claro y sin miedo", CNT 178).

Esta última construcción pódenos servir de exemplo tamén para mostrar casos especiais - por confrontación co castelán- de réxime verbal ir en ("va en el molino”, MN 95; “¿No va en los Pazos el señor abad? [...]. - [...] No, va en misa, MN 292), mallar en ("Yo mallé en ellos... como quien malla en centeno", $C N T$ 254), etc. (“¡Cuántas noches de invierno tengo salido a las liebres!”, CNT 233).

Polo que respecta ós elementos nominais pódese destaca-la presencia do artigo con nomes propios nalgún caso (la Juliana, CNT 377). Máis interese ofrecen os pronomes, pois, como é sabido, neste casos a gramática do castelán e a do galego presentan máis peculiaridades. O galego emprega os pronomes persoais átonos en casos que o castelán descoñece, por exemplo o denominado "dativo de solidariedade" ("esto de estar enfermo [...] le tiene su aquél”, $M N$ 377; “¡A fellas que los chiquillos nácente y médrante más pronto que los carballos!, CNT 49) e, por outra banda, usa con moita menos frecuencia os pronomes pseudorreflexivos ("largó de casa, y no se sabe a derechas el motivo", $M N$ 293; "¡Tantos años que largaste de aquí", CNT 306; "salvó milagrosamente de dos o tres asechanzas", CNT 204), "el muchacho me parece que salvará", CNT 315; "en casa había mucha falta de todo... Mi «ma» no sabía como arreglar...", CNT 498).

A colocación do pronome persoal átono ofrece no galego (e en xeral nas falas do noroeste hispánico) unha serie de peculiaridades que permiten utilizalo doadamente como factor caracterizador. Emilia Pardo Bazán comprende a importancia deste trazo, de que dá conta abundantemente. Con todo, a literatura castelá, por arcaísmo, ten tamén certa tendencia á posposición dos pronomes persoais. Como resultado, en ocasións resulta difícil determinar se estamos ante un risco caracterizador do galego ou un risco literario da autora. Con todo, na fala de determinados personaxes e en combinacións impensables en castelán a intención caracterizadora é clara:

-¡Quísome coger ese condenado! ¡Agarróme del pelo! (CC 154).

Mi madre... dejóme en el muelle de Marineda y se embarcó para Boenos Ayres (CNT 497)

$\mathrm{Al}$ pobre que anda a las puertas sábele bien el saco relleno de paja triga o el montón de poma (CNT 504). 
Te non aflijas, Mariniña, que hamos de tornar pronto (CNT 183).

-No sé qué le dar, ni qué le hacer (CNT 313).

¡Y bueno es el tío Amaro para lo consentir (CNT 497).

Con nos sufrir ganan el Cielo, porque es peor nos sufrir que darnos caldo y cama $(C N T 498)^{27}$.

Noutros casos a autora chámanos máis a atención porque dá conta de fenómenos que conforman aquilo que os gramáticos do XIX denominarían o xenio da lingua, a que só pode acceder alguén favorecido por extraordinarios dotes de observación:

Referímonos, por exemplo, ó emprego

- Do infinitivo conxugado:

¡[...] ella muy bien descansada con sus criadas para la descalzaren! (CNT 75).

- Do pronome neutro el pleonástico que antecede certas cláusulas:

El haber hay en la casa un rebumbio de dos mil júncaras (MN 293).

- Do rexeitamento da contestación directa cun si, substituído pola repetición do verbo:

- ¿Bendiste? -dijo la moza.

-Bendí.

- ¿Pagáronte a gusto?

-Pagáronme lo que pedía, gabado Dios (CNT 59).

-[...] Comadre, le pido de favor que me ha de acompañar cuando entre en la botica...

-Acompañaré (CNT 137).

- ¿Ahora me gastas medias, como la hirmán del abade?

$[\ldots]$

-Gasto medias, gasto medias -repitió, sin amilanarse-. Y si las gasto, no se las debo a ninguén (CNT 289-90).

\subsection{A fonoloxía}

No nivel fonolóxico non faltan os trazos característicos da fala real. Nalgunha ocasión estes vulgarismos son tamén comúns co castelán. Por exemplo,

27 Neste punto, complicado para quen non ten o galego como lingua materna, non deixa de cometer erros hipercaracterizadores dona Emilia:

¿Qué val la comida rica, si quien hala de comer tiene el corazón atragantado en el gañote? (CNT 76).

-Finafrol... También llámanme Sidora (CNT 500). 
- Vacilación das vocais átonas (boenas, CNT 110; curazón CNT 461, fertuna CNT 187, cincoenta, CNT 313).

- Reducción de grupos cultos (indinado, MN 278; solenísima, CNT 75; dinos cabaceiros, CNT 110; aseta 'acepta', CNT 520; manífico, CNT 503).

- Simplificación no final das palabras. O popularismo lévaa tamén a preferi-las formas do tipo vusté (MN 30, 255), enfermedá (CNT378), voluntá (CNT 378, 427), mocidá (CNT 474), esclavitú (CNT 198), novidá (CNT 289), salú (CNT 306, 498), verdá (CNT 489), en troques das plenas do tipo de verdade, difíciles de documentar ${ }^{28}$.

-Metáteses: No les pedregais (CNT 491).

Máis propios do galego son outros fenómenos como a:

- Pronuncia semiconsoante do fonema /i/ intervocálico. Aínda que dona Emilia utiliza predominantemente neste caso a grafía do castelán -y- (croyo, por exemplo), nalgunhas ocasións ofrece a solución que indica unha pronunciación diferente da consonántica propia da lingua oficial: aiernoche (CC 152), jeia! (CNT 461).

- Vocalización de consonantes implosivas de grupos cultos (eusautitú, MN 256; eusageran, MN 293; faucioso, PU 250).

- Persistencia de -e paragóxico alí onde o galego común o perdeu: Félise (CNT 306, 4719, buscare (CNT 362), mirare (CNT 376), señore (CNT 377), servire (CNT 497), cos correspondentes híbridos Vírguene (CNT 298), llegare (CNT 363), tenere (CNT 363), dormire (CNT 364), tambiene (CNT 376), "ellos a trabajare, ellos a obedecere, ellos a rezare” (CNT 376), Juliane (CNT 415), árbole (PU 280).

- Epénteses: “señoritos de mi yalma” (CNT 503), “¡Yo fui, que no ella, yalma mía! $(\text { CNT 488) })^{29}$.

A importancia da gueada e a súa utilización diglósica xa foi comentada con anterioridade. Entre os trazos dialectais do galego, sen dúbida os de maior extensión e importancia son o seseo e a gheada. O seseo, implosivo ou explosivo, caracteriza a fala de abundantes personaxes, sempre de clase baixa: aprendís (CNT 70), enfelís (CNT 310), mosa (CNT 493), calsado (CNT 499), grasia (CNT 520), etc.

28 Os atlas lingüísticos corroboran esta situación. Abonda con consulta-los mapas 101 e 102 de García / Santamarina (1995, II) para comprobar como as formas verdá e salú sobrepasan ampliamante o uso das formas do galego estándar verdade e saúde.

29 Contra o esperado, a epéntese tamén se pode producir en contextos non intervocálicos "Señores del yalma" (CNT 377). 
A gheada ten menor difusión que a gueada (quizais porque aquela é unha alteración propia do galego en tanto que esta afecta principalmente ó castelán que trata de falar a xente menos ilustrada. Remitimos a Pensado / Pensado Ruiz 1983). Como acontece coa gueada, a gheada dáse na obra en casos de extrema marxinación ou de conflicto diglósico, por exemplo, en situacións formais como a do epitafio dedicado a quen fora máis que criado nos pazos de Ulloa

Aquí hacen las cenizas de Primitibo Suárez, sus parientes y amijos rueguen a Dios por su alma (PU 290).

Outra situación de conflicto diglósico prodúcese nunha conversa en Madrid mantida entre dous personaxes burgueses (Asís Taboada e Pacheco) e un "guindilla", que se ofrece a busca-lo cocheiro daqueles:

-Yo aviso, si justan... ¿Dónde está o coche? ¿Cómo le llaman al cochero?

-Este no es de mi tierra, ni nada. ¿De qué parte de Galicia? -pregunté al agente.

-Desviado de Lujo tres légoas, a la banda de Sarria, para servir a vusté (I 53) ${ }^{30}$.

Os outros casos de gheada danse en personaxes de ínfima extracción social: verjuensa, dito por un mendigo, antigo mariñeiro, borracho (CNT 519). Vemos, por outra parte, que se produce nun préstamo do castelán, como tamén o seguinte: juelga $(C N T$ 93) < güelga < huelga. Sen dúbida, non é un feito fortuíto, como tampouco o é a coincidencia nun mesmo falante de seseo e gheada. Mostra unha vez máis a observación directa os estudios dialectais mostran que seseo e gheada son en gran medida coincidentes xeograficamente, aínda que a extensión do segundo é maior. Dona Emilia debeu oír con frecuencia a fala de vellos pescadores como Nordés, que falaba deste xeito:

-Sí, señor; a pique -gimoteaba Nordẹs-. Un hombre tiene un bote para se ganar la vida, y le emprestan cuatro cuartos, a cuenta de lanses de sardina..., y luego disen que no sirve para remar, que se le acabó la fuersa..., y le llevan su bote, porque no ha pagado los cuatro cuartos del empréstamo... y lo echan a pedir limosna por el mundo adelante, que es una verjuensa, cuando el hombre se había ganado siempre con honra el taco de pan, ¡retoño! (CNT 519).

\section{Breve conclusión}

De todo o anteriormente visto dedúcese que non sería desacertado considerar dona E. Pardo Bazán unha sociolingüista en potencia. A súa capacidade de penetración

${ }^{30}$ Sabido é que a provincia de Lugo a penas se ve marcada pola gheada, menos aínda na banda de Sarria, pero non se podía pedi-la precisión dun especialista en dialectoloxía naquelas datas. Quizais por entón circulase xa algunha frase ofensiva referente ó rusticismo dos habitantes desta provincia, do tipo de "Soy de Lujo y no lo niejo", que inda hoxe se oe en zonas urbanas de Galicia, da que dona Emilia se faría eco. 
no complexo entramado dicotómico de Galicia permítelle captar toda a complexidade dun proceso de conflicto lingüístico dunha maneira que xulgamos difícil de igualar na historia das nosas letras.

\section{Bibliografía}

(Ofrécese, se é o caso, a abreviatura empregada para designala no corpo do traballo e no vocabulario final)

\section{Referencias}

Curros Enríquez, M. (1969) [1885]: O divino sainete (A Coruña: Ediciós do Castro).

García, C. / Santamarina, A. (dirs.) (1995): Atlas lingüístico galego. Vol. II. Morfoloxía non verbal (A Coruña: Fundación Pedro Barrié de La Maza).

Paredes Núñez, Juan (1983): La realidad gallega en los cuentos de Emilia Pardo Bazán (1851-1921). (A Coruña: Ediciós do Castro).

Pensado, J. L. / Pensado Ruiz, C. (1983): “Geada” y "Gueada” gallegas. Anexo 21 de Verba (Santiago: Universidade de Santiago de Compostela).

Portas, M. (1991): Língua e sociedade na Galiza (A Coruña: Bahía).

Varela Jácome, B. (1995): Emilia Pardo Bazán (A Coruña: Vía Láctea).

Velasco Souto, C. F. (1987): A Sociedade galega da Restauración na obra literaria de Pardo Bazán (1875-1900) (Pontevedra: Artes Gráficas Portela).

\section{Corpus (coas súas abreviaturas)}

CC = Paredes Núñez, J. (ed.) (1990): Emilia Pardo Bazán, Cuentos completos. (A Coruña: Fundación Pedro Barrié de la Maza).

CNT = Mayoral, M. (ed.) (1984): Emilia Pardo Bazán, Cuentos y novelas de la tierra (Santiago de Compostela: Sálvora).

$D M T$ = Pardo Bazán, E. (1984) [1888]: De mi tierra (Vigo: Xerais).

CV = Pardo Bazán, E. (1999) [1885]: El Cisne de Vilamorta, en Obras completas, I (Madrid: Fundación José Antonio de Castro).

$I$ = Pardo Bazán, E. (1981) [1889]: Insolación (Barcelona: Bruguera).

$M N=$ Pardo Bazán, E. (1985) [1887]: La madre naturaleza (Madrid: Alianza).

$Q=$ Mayoral, M. (ed.) (1991): Emilia Pardo Bazán, La Quimera (Madrid: Cátedra).

$T$ = Varela Jácome, B. (ed.) (1982): Emilia Pardo Bazán, La Tribuna (Madrid: Cátedra). 
PU = Pardo Bazán, E. (1978) [1886]: Los pazos de Ulloa (Madrid: Alianza).

MO = Pardo Bazán, E. (1999) [1889]: Morriña, en Obras Completas, II (Madrid: Fundación José Antonio de Castro).

$P L=$ Pardo Bazán, E. (1999) [1879]: Pascual López. Autobiografía de un estudiante de medicina, en Obras Completas, I (Madrid: Fundación José Antonio de Castro).

$S=$ Pardo Bazán, E. (1981) [1908]: La Sirena Negra (Barcelona: Bruguera).

\section{Obras lexicográficas (coas súas abreviaturas)}

Alonso Estravís, I. (1986): Dicionário da Língua Galega (Madrid: Alhena) [Es.].

Carré Alvarellos, L. (1982) [1928]: Diccionario Galego-Castelán (Barcelona: IGOI) [Carré].

Corominas, J. / Pascual, J. A. (1980-91): Diccionario crítico etimológico castellano e hispánico (Madrid: Gredos) [Cor.].

Crespo Pozo, J. S. (1979): Nueva contribución a un vocabulario castellano-gallego, t. II (Sada / A Coruña: Ediciós do Castro) [CP]

Cuveiro Piñol, J. (1876): Diccionario Gallego-Castellano (Barcelona: Establecimiento Tipográfico de N. Ramírez y C $\mathrm{C}^{\mathrm{a}}$ [Cuv.].

Feixó Cid, X. G. et alii, (1986): Diccionario da lingua galega (Vigo: Ir Indo) [I.I.].

Ferro Ruibal, X. (1987): Refraneiro Galego Básico (Vigo: Galaxia).

Franco Grande, X. L. (1968): Diccionario Galego-Castelán e Vocabulario CastelánGalego (Vigo: Galaxia) [FG].

García, C. (1985): Glosario de voces galegas de hoxe. Anexo 27 de Verba (Santiago: Universidade de Santiago) [Gl.].

Gómez Clemente. X. B. / Arias Freixedo, X. Ma. (1990): “O 'Vocabulario gallegocastellano' de Eduardo Pondal”, Cadernos de lingua, 2: 11-47 [Pon.].

López Taboada, C. / Soto Arias, Mª R. (1995): Así falan os galegos. Fraseoloxía da lingua galega (A Coruña: Galinova) [Fras.].

Lourenço Loução, J. L. (1931): "Lexicografia das margens do Minho", Revista Lusitana, 29: 247-276 [Lou.].

Martínez Kleiser, L. (1989): Refranero general ideológico español (Madrid: Editorial Hernando).

Mirás F. (1978) [reimp. facs. da ed. de 1864]: Compendio de gramática gallegocastellana, con un Vocabulario de nombres y verbos gallegos y su correspondencia castellana (Madrid: Akal) [Mir]. 
Otero, A. (1977): Vocabulario de San Jorge de Piquín. Anexo 8 de Verba (Santiago: Universidade de Santiago [AO].

Real Academia Galega (1997): Diccionario da Real Academia Galega (Vigo: Galaxia) [DRAG].

Real Academia Española (1992): Diccionario de la lengua española (Madrid: Espasa Calpe) [DRAE].

Ríos Panisse, M. C. (1977): Nomenclatura de la flora y fauna marítimas de Galicia. I. Invertebrados y peces. Anexo 7 de Verba (Santiago: Universidade de Santiago) [RP].

Rodríguez, F. J. (1863): Diccionario Gallego-Castellano (Coruña: Imprenta del Hospicio Provincial) [Rd].

Rodríguez González, E. (1958-1961): Diccionario Enciclopédico Gallego-Castellano (Vigo: Galaxia) [ER].

Sarmiento, M. (1973): Catálogo de voces y frases de la lengua gallega, ed. y estudio por J. L. Pensado (Salamanca: Universidade de Salamanca) [Cat.].

Sarmiento, M. (1970): Colección de voces y frases gallegas, ed. y estudio por J. L. Pensado (Salamanca: Universidade de Salamanca [Col.].

Sobreira, F. J. (1974): "Idea de un diccionario de la lengua gallega", en J. L. Pensado, Opúsculos lingiiísticos gallegos del siglo XVIII (Vigo: Galaxia) [Sob.].

Tomás Pires, A. (1931): "Vocabulário alentejano", Revista Lusitana, 29: 217-225 [Pir.].

Valladares Núñez, M. (1884): Diccionario Gallego-Castellano (Santiago: Imprenta del Seminario Conciliar Central) [Vall.].

Zamora Mosquera, F. (1972): Refráns e ditos populares galegos (Vigo: Galaxia). 


\section{APÉNDICE}

\section{GALEGUISMOS NA OBRA DE E. PARDO BAZÁN. LÉXICO.}

Abade "-De contadito llega el señor abade" [MN 174; PU 51] (Rd.).

Abofé "Los tiempos estaban malos, abofé..." [PU 110] (Cuv., Vall.).

Acalcar "Acalcaban la hierba con los pies para cargar de una vez gran partida" $[Q$ 530] (Gl., Carré).

Acordar ('volver en si') "Me sacaron en camilla y me avispé una miaja con el fresquito de la tierra. $\mathrm{Al}$ acordar, empecé a pedir agua por amor de Dios" [CNT 268] (o DRAE dá como antiga a acepción 'espertar' e di que se usa en Salamanca) (Gl.).

Achinados "Y están achinados de dinero, 'moi ricos') [T 118] (Carré).

Adeprenda "Y el hijo de los amos..., ese, que «adeprenda» a cocer teja cuando tenga la edá..." [CNT 199] ('deprender' en Mir.) (Gl., Carré).

adivertir "Hoy ya te puedes adivertir en abarrenar, rapaz” [CNT 531] (Carré).

Afacerse "-Señora mi ama, no me afago aquí./ -Y pasado algún tiempo, ¿no te afarás tampoco?" [CNT 178] (Rd., Gl.).

Afellas "A fellas que los chiquillos nácente y médrante más pronto que los carballos [...] iA fellas que oigo la música! ¡Dichoso dél!’ [CNT 49] (afellas en Rd., Cuv., Vall.).

Agachar ('esconder') "Enemigos, a miles se le podían contar y, sin embargo, como el hombre se mantenía agachado, nadie se metía con él, temeroso de despertar a la fiera" [CNT 211] (Vall., Gl.).
Agarradiño ('tipo de baile') "A la muñeira sustituye el agarradiño, grotesca parodia de la polca húngara” [CNT 275] (ER).

Aire cativo "-Cosa de gusto no es -contestó ella-; pero mal no lo hace ese bichoco./-Mal lo hace, sí, señor. Ya sabes que trae el aire cativo" [CNT 468] (ER).

Alalaa "Al prolongar el alalaa, parecía diluir en el canto un lloro" [CNT 460, MN 118] ('alalá' en ER).

Albéitar "Yo estaba bien cerca en casa de Manuel el albéitar" [CNT 315] (vén no DRAE, pero é voz inequivocamente común en galego).

Alpendre "Calculé que sería cualquier alpendre, cualquier pajar que los dos mendigos encontrasen", [CNT 109, 487; $M N$ 105; $P U$ 29] (Pon.).

Amohado "Tenía a su derecha el barreño del amohado" [T 64] (Rd., Cuv., Vall.).

Amores ('amorodos') "Fresas rojas diminutas, llamadas amores, en el bosque" [CNT 347; MN 181] (Sob. e Rd. cítanos como planta distinta).

Amorotes "El claro y agrio mosto, que huele como los amorotes bravos y las moras maduras" [CNT 405] (Sob., Cat. e $\mathrm{Rd}$., mais só Cuv. alude a eles como un tipo de "fresas silvestres". Sarmiento e Rd. considéranos amoras).

Antroido "Parecía un Antruejo (Antroido)" [MN 164] (Carré).

Antuca "Ángela, el sombrero [...]. Ángela, el antuca a cuadritos" [I37] (I.I.). 
Anubar "La dama [...] se cubría y anubaba con las batistas de su ropa blanca" $[Q 423]$ (M. Mayoral di que é creación poética da autora, equivalente a nubar que usa outras veces; pero pode considerarse como posible galeguismo: anubado figura en $\mathrm{FG}$ e en Carré como adxectivo).

Apachucar ('apertar') "Me aterra pensar que pueden gentes sin educación apachucarme, pisarme" [ $T$ 131] (Gl. apachocar, apachacar) (FG).

Aprender ('ensinar') "- $¡ A y$ ! No me aprendieron. / -Pues, ¿qué te aprendieron, hija? ¿Coser?” [T 87] (Gl.).

Aquel (subs. indeterminado) "Esto del nacer y del morir, y del enfermarse [...], es un... un... un aquel que puede más que los animales y los hombres juntos" $[M N$ 28] (Carré; vén no DRAE).

Arcebispo " $Y$ Y el arcebispo no los mete en la cárcel?” [T 183] (Carré).

Arciprestes "Y del poético cementerio, en la falda del Montiño, con sus cuatro arciprestes y sus matorrales de zarzas" [CNT 351] (Gl.).

Arrecuncho ('anaco de terreo') "Pero existía un arrecuncho, un retal de terreno" [CNT 391] (Gl. arrecuncharse; recuncho é galego común).

Arredor "Y había puesta fuerza, muchísima fuerza «de arredor», para que no se acercasen las mujeres a nosotros" [CNT 268] (Rd., Cuv. e Vall.) (o DRAE dáo como antigo).

Arrenegar " ¿Te quieres meter en aquella prisión por toda, toda, toda la vida? Arreniégote" [T 143] (Gl. arrenegar).

Arreo "Anduve arreo un cuarto de legua" [CNT 396] (é galego común, figura xa en Col. e Cuv.) (DRAE, catalanismo).
Arrepiar "Señor, no ría, que es pecado. Estoy que se me arrepían las carnes" [CNT 213] (en Mir., ripiar, 'erizarse los cabellos') (Gl. arrepiarse).

Arreventar "Tosía que casi arreventaba" [CNT 136] (I.I., arrebentar).

Arrincar "El negocio no está en dar tanto piquetaso, sino en arrincar de cada golpe buena pella" [CNT 72, 352] (Rd., Cuv., Vall.) (arcaico no DRAE).

Arroñar ('berrar') "Y una mujer que venía de la corraliza, desmelenada, retorciéndose las manos, los arroñó. / -¡Ay Dios! ¡Virgen mía! -gritaba la mujer." [CNT 64] (Carré roñar 'berrar') (DRAE roñar, 'gruñir, regañar' en Aragón e Asturias).

¡Asús! “-¡A nadie le falta su cruz, Asús, Asús nos valga!" [CNT 75] (ER).

Atador ('compostor') " $-i E l$ atador de Boán!/ - ¿Adónde irá? / -[...] A casa de la Sabia [...]. Tiene la vaca vieja muy malita" [MN 16] (Gl.).

Atruxar "Cantando y atruxando como locos" [PU 51] (Mir., Cuv. e Vall.).

Aunar ('xexuar') “¡De quien se ríe Dios es de los bobos que es están aunando y con flatos y pasando mala vida!" $[M N$ 292] (Gl.).

Avelaneira (nome propio) "Y el viejo Avelaneira, el curandero" [CNT 390, 393] (como nome común figura nas cantigas profanas medievais; Vall. avelaneiro).

Babeco "Al fin la impacientó el obediente mutismo de su compañero. / - ¿Qué haces, babeco?", [MN 37] (Carré, DRAG).

Babiona "Temerosa de que la Comadreja la tratase de babiona y de pápara" [T 257] (Vall., Carré). 
Bailas ('bailes') "Hubo sus cohetes, sus gaitas, sus bailas, sus calderadas de pulpo" [CNT 212] (Vall., Carré; DRAE dáo como antigo).

Berberecho "Los juguetes de la niña fueron «navajas», almejas, «berberechos»" [CNT 200] (aparece no DRAE a partir de 1884 , como propio de Galicia).

Berrar "Ese berra bien...; ¡ay lo que está diciendo! (MN 278). Voz común.

Berruña "Montaba una mula berruña mansa y oronda" [CNT 240] (en Rd. documentamos un adxectivo, berrugo, co valor de ‘duro, correúdo' que lle acaería á nosa palabra. A raíz é a mesma, hai cambio de sufixo).

Bico ('peteiro') "Y va el pagarito y con el bico le saca un ojo" [PU 280] (Rd.).

Bichoco "Parecía que la salmántiga sudaba veneno por su piel rota [...]. -Cosa de gusto no es -contestó ella-; pero mal no lo hace ese bichoco" [CNT 468] (Pon., Vall., I.I.)

Birtas "El hondo prado que surcaban las birtas" [Q 530] (Rd., Cuv., Vall.).

Bocalán "Ni a romperme un vidrio se atreverán esos bocalanes. Pero conviene estar dispuesto, por si acaso" [PU 251] (Vall., Gl.).

Boeta "Dos onzas no podía hallarse sino en la boeta o cepillo de Santa Minia" [CNT 133] (Rd., Cuv., Vall).

Bola (de pan) "Hacía más de dos horas que pedían bola, aun antes de estar amasada la harina" [MN 161] (Carré).

Borrachón "Que el padre era un borrachón y se volvió tolo de la bebida" [CNT 461] (Vall., I.I.).
Brabádigo ('retoño de castaños' reza o vocabulario da autora) "Amarró firme el otro cabo de la rama y se agachó entre el brabádigo espeso" [CNT 99, 232; $S$ 154] (FG) (bravádego en Carré, brabal en Rd. e Cuv.).

Branco "«¡Cómo branqueas, Mariniña!» "¡Y tú qué branco te tornas!»" [CNT 182] (Cuv. e Vall.).

Branquear " « $i$ Cómo branqueas!» «iQué branco!»” [CNT 182] (Vall.).

Brétema "La niebla era húmeda: en aquel lugar montañoso convertíase en «brétema», e imperceptible y menudísima llovizna calaba a las dos comadres" [CNT 140, 205] (Rd., Mir, Cuv. e Vall.).

Brincos ("pendentes') "El "paño" de seda y los brincos de filigrana" [CNT 252; $P L$ 125] (Carré) (Figura no DRAE. Cor. di que vén do portugués)

Brona "La artesa, bruñida a fuerza de haberse amasado encima el pan de brona" [CNT 241; MN 162] (Gl.).

Bruar [S 131] (Rd., Cuv., Vall).

Brután "Calla, brután... ¿Quién piensa en cuchillos?" [CNT 520, 73] (I.I.).

Bunitas "Sus requiebros y ternezas son siempre para las rapazas, las nenas bunitas" [MN 126; PU 277] (Gl.).

Burel "Arrebujada la cabeza en su mantelo de burel" [CNT 45] (Cuv., Vall., Carré).

Cabaleiro (alcume) "José el Cabaleiro" [MO 861] (DRAG).

Cabrifollos "En cuyo lindero manzanillas y cabrifollos despedían grato aroma" $[P U$ 65] (cabrinfollo en Rd., Cuv., Vall e Carré; cabrifolla en Sob.). 
Cadril "Le ha salido, perdonando vustedes, una tumificación muy atroz en los cadriles" [MN 17] (Rd., Cuv., Vall.).

Cainzas "Los carros célticos, con sus ruedas macizas, sus cainzas de mimbre negruzco" [ $Q$ 530] (Vall., Carré).

Caldelo (alcume) "Pero el Caldelo, un valentón de marca, murmuró..." [CNT 421] (como voz común, en Carré).

Cara lavada “¡Valiente «cara lavada» [CC I / 111] (I.I. caralavada 'descarado, cínico', ER).

Cara (a) (loc. prepositiva) "Convinieron en dirigirse cara allá", [CNT 39, 36, 79] (Vall., Carré).

Carapachos "(La luz del sol) en los carapachos de los escarabajos [...] encendía tintas vivas" [MN 186] (Carré 'caparazón de la centola y otros crustáceos').

Carballo "Los chiquillos nácente y médrante más pronto que los carballos" [CNT 49].

Cardeñas ('especie de fouce') "Había risotadas ofensivas [...] y puños que apretaban mocas y cardeñas" [CNT 298] (Rd., Vall., Carré).

Caristoso "Ello no quita para que el trabajo sea caristoso" [CNT 459] (ER).

Carón, $\boldsymbol{a}$ "Tú llévame a carón de la barca y te diré..." [CNT 520] (Carré).

Carracha (alcume) “¡Pues lo que es él, Carracha, no se movía de allí!" [CNT 40] (Rd., Cuv., Vall., Carré).

Carranqueo "Entraba el coche de Orense [...], y al resonar sus cascabeles y campanillas, el trote de sus ocho mulas y jacos y el carranqueo de su pesada mole, los vecinos de Vilamorta se colgaron de los balcones..." [CV 674] (esta voz, da familia de carranchas, carrancholas -variantes carrancas, carrancolas en Gl.-, 'escarrancharse', alude ó movemento que se fai ó andar; temos carrandear en Carré e GL co sgdo. de 'andar movendo moito as cadeiras', e un verbo carranquear 'andar' aparece tamén en Gl.).

Carretón ('home que carga') "Los carretones se derriten al ascender con las cargas, magullados los hombros con el peso" [CNT 459; CV 755] (I.I.).

Caruncho "Cata que sale una mosca verde del estiércol y te pica..., el caruncho sea contigo, y acabose", $[M N$ 291] (Rd., Cuv., Vall., Carré).

Casabé ('prenda') "Tan modosa [...], con su casabé abrochado hasta la nuez" $[P U$ 49] (Carré).

Castizar ('procrear') “¿Como los marranos? ¿Comer, dormir, castizar, y luego a podrirse en tierra?" [MN 292] (Vall., Carré).

Cativo ('neno') "Al fin, los cativos ya estarían muertos; su llanto no se oía" [CNT 439; MN 147] (Carré).

Cativo ('malo') Vid. aire cativo, ramo cativo.

Cedo "Salió esta mañana cedo" [CNT 313] (Rd., Mir, Cuv., Vall.; arcaísmo do norte no DRAE).

Cinta ("algas marinas" no vocabulario da autora) "Huele a marea viva y a yodo, como las recias «cintas» y los gruesos «marmilos» de la costa cantábrica" [CNT 200] (FG).

Cirolas "Los blancos calzones de lienzo llamados "cirolas"” [CNT 251] (Rd., Carré). 
Ciscar "Que se cisca en lo que le de je por testamento y que no quiere de él ni la hostia" [MN 278] (Carré, DRAG; vén no DRAE; é voz común ó galego, ó portugués e ó castelán, probablemente de orixe expresiva, vid. Cor.).

Clas "Se crían repollos, y patatas, y toda clas de hortalizas" [MN 30] (Carré).

Cocón "¡Si no callas, viene el cocón y te come!” [PU 277] (Gl.).

Codelo (alcume) "Martiño el Codelo" [CNT 426] (Carré).

Cogulo, $\boldsymbol{a}$ (frase adverbial, 'cheo a rebordar') "Tres platos llenísimos a cogulo" [CNT 41] (acugulo en Vall; cogulo en FG; documentamos a fr. adv. en falante de Sendelle, Boimorto, Coruña).

Coleiro "al llegar exhaustos de subir el pesado coleiro o cestón henchido de uva" [CV 755] (vid. culeiro).

Colo "Tenía en el colo toda la tarde un mamón ajeno" [CNT 338] (Cuv., Vall.).

Cómaro "El cuerpo recostado en el cómaro mullido de madreselva y zarzarrosa" [CNT 66] (Rd., Cuv., Vall.).

Compango "La familia despachaba el caldo calentito y el compango de cerdo" [CNT 132, 460] (Rd., Cuv., Vall., Carré).

Compaña "En las noches sin luna, vemos pasar con sus antorchas sepulcrales la misteriosa procesión de la Compaña" [PL 113], "Al ver entrar el algebrista y la compaña, la bruja se enderezó" [MN 19, 254; PU 193] (Rd., Cuv., Vall., Carré).

Compostor ('curandeiro') "Reduciendo luxaciones y extirpando sarcomas, merced a no sé qué ciencia infusa o tradición comunicada hereditariamente o recogida de labios de algún compostor viejo" [MN 25] (Carré).

Compridas ('grandes') "Tienen sus boenas camas compridas, con sus seis colchones para la blandura" [CNT 110] (Rd., Carré).

Conversa "Muy habladero; que daba conversa a todo el mundo" [CNT 61] (Vall., Carré; vén no DRAE).

Corcia “ ¿Cómo no había pensado en eso, corcia?”, [CNT 462] (;corcio! en ER).

Corredoira "Pasando algo tarde por la corredoira que a sus casas conducía" [CNT 472; MN 171, 250] (Rd., Cuv., Vall.).

Cortiña ('terra de labranza') "Manuela fijó los ojos en la cortiña segada" [MN 157] (Rd., Cuv., Vall., Carré).

Corvo (alcume) "No te encuentres con el Corvo, que te la tiene jurada" [CNT 415] (Rd., Cuv., Vall.).

Crebado "-Con perdón -respondió el Sarnoso, tocándose una pierna-, llevaban esto crebado" [MN 116] (Cuv., Vall., Carré).

Croyo ('pedra') "-Fue que di contra un croyo" [CNT 308, 393] (Pon., Rd., Cuv., Vall., Carré).

Cuasimente "Al llegar al puerto iba dando "cuasimente» las boqueadas" [CNT 268; $T$ 160] ('cuasemente' en Vall e Carré).

Cubicia ('cobiza') "De aquí viva no saaal...ga si otra triste hilacha de taaab...aco apañé...; que yo no lo hiiiice por cubicia" [ $T$ 209] (cubizoso en Mir, cubiza en Cuv. e Vall.).

Cucorrei "Oyó fuera la convenida señal, el canto del cucorei..." [CNT 83] (ER) (A 
palabra forma parte dun recitativo popular infantil "Cucorrei, cucorrei, ¿cantos anos vivirei?, ¿vintecinco? Non o sei. Un, dous, tres...").

Cucho "No le secase la vaquiña, que de esta hecha se le moría, y el cucho también" [MN 183] (Rd., Cuv., Vall., Carré).

Culeiros ('cestos') "Subir a hombros los culeiros o cestones" [CNT 459] (Carré).

Cumplir ('ser necesario') "Y a dormir, que mañana cumple madrugar" [CNT 94, 136, 307; $P U$ 9] (I.I.; vén no DRAE).

Cunca "Te voy a echar el caldo en la cunca" [CNT 92, 396; MN 183] (Rd., Mir, Cuv., Vall).

Curazón “¡Tenedes mal curazón pra metervos con quien no se mete con vosotros!" [CNT 461] (Carré).

Curral "Metiéronse en la casa por la parte del curral de la era" [CNT 377) (Carré).

Curro "Revolcándose entre el estiércol del curro" [CNT 53] (Rd., Mir.).

Currusco "Sosteniendo el currusco de pan" [Q 545] (I.I.).

Cuxo "Llevando de la cuerda su mejor ternero. "Andrés, adónde vas con el cuxo?" [CNT 206] (Cuv., Vall.).

Chaleque "De jó de lucir el calzón de rizo azul, el «chaleque» de grana" [CNT 193, 251] (Cuv., Vall., Carré).

Chaminé "Nos rompen siempre los oídos pidiendo... Que una chaminé, porque los mata el humo" [MN 164] (chaminea en Carré; I.I.).

Chapeo "Voy a apañar mi sombrero [...], me veo debajo una serpiente [...], y valió que le dio idea de esconderse en el chapeo" [PU 204] (Cuv., Vall., Carré; antigo no DRAE).

Charamuscas "La llama, chisporroteando, se elevó, y brotó centellas volantes, charamuscas rápidas", [Q 542] (Rd., Mir, Cuv., Vall; galeguismo recoñecido no DRAE).

Chascarrás ('ruído das cunchas') "Una algarabía, un chascarrás desapacible" [T 83] (ER, chascarraschás).

Chícharo "Pollos con «chícharos»" $[C N T$ 255] (Pon., Rd., Cuv., Carré; vén no DRAE).

Chisco ('grolo') "Echen un chisco, caliéntense" [CNT 84, 268, 398, 493] (mesma acepción en Rd., Cuv., Vall., Carré).

Chosca (alcume) “¿No había visto Marijuana la Chosca, con su único ojo...?" [CNT 75; PU 280] (Cuv., Vall., Carré).

Choyo ('traballo') "Un contratista, hombre agenciador, que hacía el negocio de proporcionar gente [...], con él, seguros estaban de tener choyo todo el año" [CNT 71, 217] (Pon., Cuv., Vall.; no DRAE só figura a acepción 'ganga').

Chuchiña (apelativo cariñoso) “ ¿No te da gusto tomar el fresco, chuchiña?" $[M N$ 37].

Churrusqueiros "La de más almidonadas enaguas, limpias medias, rollizos mofletes y alegres y churrusqueiros ojos que tenía el país" [MN 61] (Rd., Cuv., Vall., Carré).

Deixada (alcume) “¿Quién se arriesgaría a visitar a la Deixada" [CNT 365].

Demo "Tentóles el demo" [CNT 377] (Rd., Cuv., Vall.). 
Denantes " $\mathrm{Y}$ a beber y a pastar como denantes" [CNT 244].

Dengue "El «dengue» majo, la randada camisa de lino" [CNT 252] (Cuv., Vall., Carré; vén no DRAE).

Deprender "Sedes más tontos que los que nunca tal deprendimos" [CNT 472] (Carré).

Derrearse "No va a derrearse de trabajo un hombre de bien" [CNT 494, MN 230] (Rd., Cuv., Vall.).

Desenferruxar "Se «desenferruxaban» armas blancas y de fuego" [CNT 154] (I.I.).

Desmirriado "No vas a valer; estás desmirriado; eres un papulito que siquiera puedes con la herramienta" [CNT 72] (documentámolo en falantes de Segán de Abaixo, Currelos, Lugo; no DRAE vén como posible leonesismo. Vid. esmirriado).

Diaño "Largar pesos al boticario, que el diaño cargue con él", [CNT 45, 84, 415; $M N$ 293] (Rd.) (no DRAE vén como eufemismo de algunas partes).

Dona "Juan, indeciso, no esperaba sino el consejo, la excitación de la dona" [CNT 94] (Carré).

Ducia "-Sepamos ¿a cómo te pagan? -Dos cuartos por la ducia" [PU 138] (Rd., DRAG).

Eia " ¡¡A ver si vos callades, eia!" [CNT 461] (Carré).

Empatar "Se apresuró a acercarse con su magnífica pareja de cebones para empatársela a otros vendedores" (I.I. 'causar embarazo').

Emprestar "-Darlas, ya se sabe; pero... emprestadas... -¡Emprestadas! Sí, ve a que te empresten..." [CNT 134] (figura no DRAE como vulg.; en gal. é voz común, vén no DRAG).

Empurrar "Mismo así, empurrando, empurrando..., echóme por la puerta" [CNT 138] (Rd., Carré, DRAG).

Encanfurnado ('emparedado, oculto') "Existían onzas, un montón de oro, encanfurnado en un rincón que sólo el amo y el mayordomo sabían" [CNT 80] (Carré, I.I.).

Encarranchado ('escarranchado'). "Saltó del banco donde estaba encarranchado" [CNT 290] (acarrancharse, escarrancharse en Gl.; documentamos esta variante en falantes de Currelos, Lugo).

Ende (seguido de xerundio) "-Ende tornando yo contigo, asosiégate" [CNT 58, 429] (Carré).

Endrómena ('argallada, trola, conto') “¿Tú no sabes que el tren va por carriles, y esta endrómena por todas las carreteras, hom?" [CNT 97; MN 28, 293] (Cuv., Vall., Gl.).

Enferrizado ('con ferruxe') "(El escaparate luce) tijeras enferrizadas, navajillas tomadas de orín" [CC I / 96] (enferrujarse en Vall.; enferrollar, enferruxar en Gl.).

Entrapallar ('atrapallar as palabras') "Habla el señor... ¡No se oye miga!... Todo lo entrapalla con toser y con la rabia que tiene" [MN 278] (Gl.).

Escandecida ('quentada') "La sabrosa trucha busca la capa de agua densa y no escandecida por el sol" [ $M N$ 188] (I.I.).

Escarranchado " Así Dios me salve, le tumbo escarranchado!" [CNT 79] (Rd., GL; no DRAE vén como posible galeguismo). 
Escomenzar "Y el «arremolino» de la gente..., escomenzaron a decir..." [CNT 268] (Gl.).

Escotar "-¿Quieres escotar un cachito de siesta?" [MN 208; PU 61, 204] (a frase feita documentámola en Es.; o verbo escotar 'descabezar' é común: figura por exemplo no Gl.).

Escribido ('culto, sabido') "El barbero, que era leído, escribido y muy redicho" [T 90] ('erudito' en Carré).

Escrupol "-¿Saben qué es ese escrupol que le da con el vino a Rosiña?” [CNT 461] (escrúpalo, escrupo en ER).

Escurecer "Pero luego escurece, ¡escurece!, y un hombre, aunque se quiera valer con la capa, no se vale" [CNT 110] (Gl.; no DRAE vén como antigo).

Esfarraparse "Hubo alabanzas a la guisandera. ¿Que guisase así hasta esfarraparse de vieja!” [Q 547] (Rd., Gl.).

Esganar “-¿Quiérese ir contigo ese peine? ¡Ya lo sabía yo, muller! Le voy a esganar hoy mismo" [CNT 429] (Rd., Gl.).

Esgarrichado ("bebido ata o último gurrucho') "Sacó el frasco [...]. Apenas éste lo llegó a los labios, botó furioso -¿Quién es el hijo de can que me ha esgarrichado la caña?" [CNT 488] (esjurrichar en Mir., esgurruchar en Rd. e Cuv., escorrichar en Pon.).

Esmagar " ¡Si yo tuviese una piedra con que esmagarte de los sesos!" [MN 153] (Rd., Carré).

Esmigar ('desfacer') "Si soy otra la mato, la esmigo con los pies" [CNT 378] (esmi(n)gallar, esmigaxar, esmincallar en Gl.; esmigar en Currelos, Lugo).
Esmirriado "-El puño y la bota, y peor para la gente esmirriada" [CC I / 119] (esmirriado, esbirriado en Gl; esmerruxado en $\mathrm{AO}$; Cor. di que hai motivos de sobra para considerar a palabra de orixe leonesa ou galego-portuguesa).

Espesiallo ('refugallo de arume que cae a cada golpe de machada nos piñeiros') "Madera verde [...] cubierta por el espesiallo de finas púas, que caía a cada golpe" [CNT 307] (espiñalla en Carré).

Espetar "Meto ganado y un criado en la casa, espeto el arado en la tierra" [CNT 473] (espetar, 'meter, introducir' en Mir.; Cor. traza a posibilidade de termos aquí un suevismo galaico).

Espiga reina ('espigas de millo vermellas') [S 127] (Gl.).

Espilirse "No explicaba muy satisfactoriamente el sobrino su impensada venida "¡Pchs..., ganas de espilirse... Cansa estar siempre solo" $[P U$ 85] (Rd., Carré).

Espinallo ('Garabulliños secos dos piñeiros que caen ó chan') "Ayudó a la vieja a cargar el haz de espinallo" [CNT 379] (Gl.).

Espricar "La mochacha no esprica [...]. Esto de la posada lo hay que espricar" [CNT 110] (Gl.).

Esquecer "Se le había esquecido mudar la toalla”, [PU 47] (Rd., Mir, DRAG).

Estadea (alcume) "Llamáronla la Estadea, nombre que da la superstición popular a una procesión de espectros" $[T$ 172] (Carré).

Estripar " $\mathrm{OO}$ te estripo, o las bendiciones del cura, que lo que naciere, mediante Dios, padre ha de tener!" [ $C N T$ 448; $M N$ 27] (Rd., Carré). 
Facatrús ('cabalo do país') "El facatrús pertenecía a la exigua y resistente raza del país" [CNT 299] (FG).

Fachón" "A la luz de los fachones de paja de centeno" [PU 51] (Gl.).

Fadas "Pocas son las malas fadas" [MO 897] (é frase feita, vén en Carré 'poco hay que esperar, poco falta').

Fala "Uno de los carretones más animosos y robustos, que a cualquiera de ellas le convendría para darle fala" [CNT 461] (Rd.).

Falcatrúa “ ¡Estamos frescos! ¡Ay, don Gabriel, de aquí va a salir una falcatrúa!" [MN 309] (Rd., Carré).

Faldra “¡Lamelonas! ¡Porcallonas! ¡No tenedes faldra en la camisa!" [CNT 302] (Carré).

Fallado "Cunchiña y yo dormimos en el fallado", [CNT 427] (Gl.).

Fecharse "¿María Lorenza y yo íbamos a quedarnos sentadas o a fecharnos en el desván?” [CNT 80] (Rd., Cuv., Vall.).

Feixe "Pouse el feixe, muller... Yo ayudo" [CNT 376] (Rd., Cuv., Vall.).

Femias "Ahora se vería si las otras, las femias, hacían más" [CNT 72] (Cuv. e Vall.) (fémea en Rd.).

Ferido "Era preciso estar como estaba yo, $\tan$ ferido de punta de amor" [CNT 355] (no DRAE figura como antigo).

Ferrado "Estaban arrendados por seis ferrados de trigo anuales" [CNT 174, 377] (Cuv., Vall.).

Ferradura "-La yegua [...]. -Está sin una ferradura siquiera" [PU 76] (Rd., Cuv., Vall; o DRAE dáo como antigo).
Ferranchinería "La distribución y empleo de aquella ferranchinería escondida con tanta habilidad" [CNT 86, 444] (ferranchar, ferranchín en Carré).

Ferrancho "Aquel ferrancho - la daga- la arrojarían a la bahía" [CNT 420] (Rd., Cuv., Vall., Carré).

Fertuna "¡Cosas de la «fertuna», que «vira» como el viento!" [CNT 187] (Vall., Carré).

Fiadas "Y se repiten en molinos, fiadas y deshojas, al amor de la lumbre" [MN 171] (Rd., Cuv., Vall., Carré)

Fillo "-Las dos fillas mías echan la sangre a golpadas" [CNT 313], "Calla, filliño, calla... toma el chocolate" $[\mathrm{CV}$ 664] (Rd., Cuv.).

Filloa "Vinieron los gordos Carnavales, con su escolta de ollas tocineras y de filloas amarillas", [CNT 86] (Rd., Cuv., Vall.; no DRAE figura como galeguismo).

Finafrol (antropónimo, título dunha novela curta) [CNT 481] (frol en Carré).

Fitar "Añadió Pastora, que parecía zahorí, según fitaba en mi conciencia" [ $P L$ 177] (no texto ten valor metafórico; no sentido de 'mirar fixamente' é voz común e vén no DRAG).

Fiúncho "Flotaba la fragancia de la espadaña, fiúncho y saúco en flor" [CNT 321] (Rd., Cuv., Vall.).

Fleque "San Antón le está poniendo una ropa toda de oro, y de plata, y de perlas, con unos fleques colorados" [CNT 49] (Vall., Carré).

Fol "Oprimir bajo el sobaco el fol de la gaita" [MN 127; PU 53] (Rd., Mir, Cuv., Vall.). 
Foleto "El corazón de Pacheco, como espíritu foleto que obedece a un conjuro, rompió en el más agitado baile que puede ejecutar semejante víscera" [ $\left.\begin{array}{l}I \\ 159\end{array}\right]$ (a palabra debe emparentar con outras da familia de fol: folán en AO 'home brando e sen forzas'; foco, folopo 'huero, hueco' (AO); foleiro 'dise das crianzas inquietas' (Lou.); lobo foleco (insulto oído en Valencia do Sil, Vilamartín de Valdeorras, Ourense); foleto ben pode estar formado como foleco, cfr. buraco=burato e o significado que lle acae no texto de Pardo B. podería aproximarse ao de 'fofo, sen forzas', que é traído e levado polo vento da paixón facilmente, ou senón arrimaríase á idea miñota de 'espírito inquedo, tolo').

Follato ('follas do millo') "Dejó suavemente sobre la almohada de follato la cabeza" [CNT 46, 488] (Cuv., Vall., Carré).

Fraga "Sentados juntos en la umbría de la tupida «fraga»" [CNT 181] (Rd., Cuv., Vall.).

Fretir “ ¡Fretirlo como si fuera un pancho...!" [T 243] (fritir en Mir., Gl.).

Friaje "¿Qué importaba un poco de friaje? Ya se calentarían bien" [CNT 39, 75] (Rd., Cuv., Vall.).

Frieiras "La trucha [...] suele refugiarse [...] en ciertas hondonadas o pozos profundos llamados en el país frieiras, donde encuentra el agua helada casi" [CNT 263; MN 188] ('regacho' en Vall., 'paso estreito de auga no río' no Gl.).

Fusique "Trémulo, con los espejucos torcidos y el fusique oprimido en el crispado puño" [PU 247] (fusique, fuchique en CP; o DRAE di que o usaban, polo común, galegos e asturianos).
Futrar ('evacua-lo ventre') "Sepan que yo no quiero sus riquezas y que me futro y me refutro en ellas" [MN 263] (Vall., FG).

Gándara "Como se internasen en la escueta gándara que precede al lindo vallecito" [CNT 140] (Rd., Cuv., Vall., Carré; Cor. di que a toponimia testemuña a maior vitalidade de gándara en Galicia).

Garduña ('ave de rapina' no vocabulario da autora) "Reconocí al ave de rapiña [...]. Poco a poco, [...] la garduña fue bajando" [CNT 221] (Es; en falantes de Currelos, Lugo).

Gargalladas "Nuestra Señora está alegre, el bendito San Antón está que hasta pega gargalladas", [CNT 49] (Carré).

Garroso (adx. referido ás canelas dun home) "La delgadez de sus miembros, el hundimiento del jadeante esternón, la pobreza de las garrosas canillas" [ $T$ 166] (a única acepción válida que atopamos parécenos esta: Garrudo 'guedelludo' en Pir.).

Gayola "Varios objetos cinegéticos, gayolas (jaulas)", [PU 25] (Cuv., Vall., Carré, DRAG; vén no DRAE).

Gobernar "Te he puesto una tartera de bacalao gobernado con patatas", [CNT 92] (parece unha ampliación do significado 'arranxar, compoñer', Carré, I.I.).

Golfín ('arroaz') [S 133] (golfiño en Vall. e Carré; golfín en GL; figura no DRAE).

Golfo (de sangre) ('acumulación, borbollón') "Un golfo de sangre salía de la herida" [CC I / 114] (golfarón en Gl.; golfo de auga en $\mathrm{AO}$ e I.I.). 
Golpadas, $\boldsymbol{a}$ (fr. adverbial) "-Las dos fillas mías echan la sangre a golpadas" [CNT 313] (golpada en AO e ER).

Gramalla ('cadea que suxeita ó can') "Bobita se disparó de la perrera como demente $[\ldots]$, y arrastrando al criado que la asía por la gramalla" $\left[\begin{array}{ll}Q & 513\end{array}\right]$ (constatamos na fala a acepción 'un ferro que se poñía fóra da casa para colga-la pota' nun informante de Betanzos; 'gramalleira', claramente emparentada, é voz común e vén no DRAG).

Gunía “La Virgen Nuestra Señora que me resucitó estando yo en las ansias de la gunía” [CNT 324] ('agunía' en Carré).

Gunizar “ ¿Es el estertor! ¡Está gunizando!" [CNT 46, 323].

Hastra "¡Si "hastra" más flaco parece!" [CNT 199] (Cuv., Vall., Carré; atra na lírica medieval).

Herbeiro "Una vivienda mediana, unida a la pajera, herbeiro y establos" [CNT 473; $P U$ 135, 276] (Gl.).

Hirmán “-¿Ahora me gastas medias, como la hirmán del abade?" [CNT 289] (Rd., Mir, Cuv., Vall.).

Hom "-Vay, bueno, hom, no te avergüences" [ $C N T$ 415, 426; $C V$ 651; $Q$ 141] (Carré; ;ho! vén no DRAG).

Home "Es un pecado, home" [MO 822, 824] (DRAG).

Huchas ('arcas para alimentos') "Robando la plata de las iglesias, el tocino de las huchas" [CNT 400] (Cuv., Mir, Vall; vén no DRAE, galicismo).

Húngaros ('xitanos') "Un campamento de húngaros en el soto de Lama" [CNT 464] (oído en Deza e Trasdeza).
Ichavo "No tengo un ichavo triste" $[P U$ 203] (Carré).

Imitarse ('parecerse') "Siempre te imitaste más a Gabriel y a mí que a tu madre" [PU 83] (Carré, Gl., DRAG).

Inda " $\mathrm{O}$ el diaño, que inda es más listo! [MN 293] (Rd., Cuv., Vall.).

Lages "Las herraduras de un caballo. Resbalaban en las lages, y sin duda arrancaban chispas" [CNT 309, 462] (Rd., Cuv., Vall., Carré).

Lai ('queixa') "Una especie de gemido cuya base era triste ¡lai..., lai!, la queja lenta y larga de todas las canciones populares en Galicia" [PU 191] (lai na lírica galego-portuguesa medieval, referido a un tipo de cantiga; laio, laído en Gl., DRAG).

Lambon, -aza ('aproveitado') "Las nietas de la Sabia y otras lambonas que sólo andaban tras la intriga y a la socaliña del pedazo de pan" [MN 253, CC I/105], "Si el criado fuese como los vagos y lambones que andan de casa en casa" [MN 291] (Carré).

Lampona ('sinvergonzona') “-¡Andar, lamponas! ¡Dejáis la cama por hacer y el chiquillo por mamar! ¡Madrastras!” [T 127] (lampanas 'sinvergonza' en AO, lampantín en Cuv., lampo ‘desvergonzado' en FG).

Langrán "Un tagarote con bocio conocido por Langrán" [CNT 489] (Carré).

Lanzal "Un rapaz que era un lobo para el trabajo, tan lanzal, tan amoroso" [CNT 471] (Vall., Carré, DRAG).

Lapa (alcume) "Y quien sacará mañana la embarcación será el Lapa" [CNT 531] (Mir). 
Lapo ('labazada') "La abuela [...] le dio un pequeño lapo para que se apartase" [MN 160, T 209] (Vall., Carré; no DRAE figura como propio de Ar., Sal., Vizc., Chile e Méx.).

Lareira "El calor de la lareira no era apetecible ya" [PU 46] (Rd., Cuv., Vall., DRAG).

Larpán “¡Ve a dormir la mona, cuero! ¡A la taberna con tus huesos, larpán, tonel de mosto!" [PU 254] (Rd., Cuv., Vall., DRAG).

Leira "Sin tropezar con la «leira» trigal, el prado de regadío" [CNT 232] (Rd., Cuv., Vall.).

Leite "Yo soy nieta de la tía Margarida de Leite" [CNT 58].

Leito "Para Minia la cama en el duro suelo; para Melia un leito igual al de sus padres" [CNT 132, 247, MN 162] (Rd., Mir, Cuv., Vall.).

Lercha " ¡Hay cada sargentona y cada lercha!” [MO 808] (DRAG).

Leria "Con un sólo vocablo regional [...], expresó el marido su incurable desconfianza -¡Leria, leria!" [CNT 429; $P U$ 70] (Rd., Mir, Cuv., Vall.).

Lesta "Entre espliego, "lesta" y olorosas manzanas" [CNT 252, 522; $Q$ 457] (Rd., Cuv., Vall.).

Liña ('fío de pescar') [S 166] (Mir, Cuv.).

Lirios ('ratas') "Y fue meter una rata enorme de las que en Marineda se llaman «lirios», en una cajita de madera" [CC I/93] (liria en Cuv., lirio 'rato grande' en Rd.).

Lirpa ('peixe parecido ó linguado') “Y pollito asado, lirpas y marisco" [ $Q$ 514] (Carré).
Liscar "¡Afoera con ellos ahora mismo, lisca!”, [CNT 499] (Vall., Carré).

Luciola ('vagalume') "Una corredoira [...] alumbrada a la sazón por la luz suave y espectral de las luciolas" [ $[M N$ 250] (lucio 'lúcido' en Vall., lucio 'hierro incandescente para hacer alguna operación a un animal' en Glos.).

Macheta "-¿ ¿Yo qué sé? También se podía venir paseando. - ¿Paseando con la macheta?" [CNT 305] (Rd., Vall., Carré, DRAG; DRAE León e Sal.).

Madama "Aquella luz [...] semejante a la que despedía la «madama de fuego» que presentaba el cohetero en la fiesta patronal" [CNT 134].

Madrugueiro (alcume) [ $C N T$ 360 $]$ (Carré).

Magostos “ ¡Pocas veces me los tengo encontrados por los sotos, haciendo magostos" [MN 109] (Rd., Cuv., Vall., Carré).

Maino "Cibrao, maino como una oveja" [CNT 176, 312; $M N$ 27] (Cuv., Vall., Carré).

Mainzo "El mainzo, este año, por falta de lluvias, iba a perderse" [CNT 471; $M N$ 30] (Rd., Cuv., Vall.).

Mal novo "Los bueyes, que enfermaron del mal novo, científicamente llamado glosopeda" [CNT 426].

¡Malaña! ('mal haxa') "- $-\mathrm{Si}$ pasa el juez..., se la tiro! ¡Y le acierto en la sien, malaña!" [CNT 464, 465].

¡Malacaste! “¡Malacaste! Oye, tú” $[M N$ 195].

Malia " $-¡ S i$ supiese yo quién fue [...], malia para él!” [CNT 392] (Vall., Carré). 
Malpocado “-¡Teney vergüenza! Soltay los cuartos! ¡Eso es de la malpocada!" [CNT 67, 322; MN 270, MO 861; CV 695] (Cuv., Vall., Carré, DRAG).

Mallador "Corría entre los malladores halagüeño murmullo" [MN 227].

Mallar "Yo mallé en ellos... como quien malla en centeno" [PU 254] (son galegos tanto o verbo coma a frase feita "mallar en alguén coma quen malla en centeo (verde)", Fras. nº 1997 e 2073).

Mallo "Se quedaba apoyado en su mallo y gritaba..." [MN227].

Mamai "Los chiquitines decían al molinero y a la molinera papai y mamai" [CNT 129] (Carré).

Mancar "-¡Ay si me lo mancan!... ¡Juaniño!” [CNT 95, 268] (Rd., Mir, Cuv., Vall.).

Mantelo "Arrebujada la cabeza en su mantelo de burel" [CNT 45, 273] (Rd., Cuv., Vall; galeguismo recoñecido no DRAE).

Mariquiña "Mariquiña, voa, voa, que ch'ei de dar pan e ceboa" [MN 152] (trátase dun recitativo popular; na última palabra comete Emilia Pardo un hipergaleguismo).

Marmilo ('planta marina' no diccionario da autora) "Las recias «cintas» y los gruesos «marmilos» de la costa cantábrica" [CNT 200] (Es) (En Cat. Sarmiento recolle marmulo, 'un bocho de mar').

Marmonear ('murmurar') "Esta vida rueda sus ondas por la calle, bulle en el atrio [...], entra en el templo, marmonea rezos sin efusión" [CNT 423] (marmonexar en AO; marmonear 'criticar' en falantes de Currelos, Lugo).
Maruso "Yo también soy galleguiño, maruso, de pralá" [MO 788] ("ollos maruxeiros, que namoran", en GL; maruxo 'mariñeiro', en Carré; marulo 'labrador' en I.I., e 'paifoco' no castelán de Coruña; a voz rexistrada na nosa autora debe significar 'paisano', 'do pobo traballador').

Mataburrillo "El guiso de intestinos de castrón, hígado y bofes, llamado en el país mataburrillo" [PU 55].

Medadoras ('mulleres que fan medas') "Cuando por casualidad las medadoras [...] se volvían hacia la terraza..." [Q 530].

Medar ('facer medas') "Lo sentaba y colocaba espiga adentro, medando hábil y rápidamente" [ $M N$ 124, $Q$ 529] (Cuv., Gl.).

Medas "Cebado el incendio con la hierba seca de las medas" [CNT 400; MN 114, 118, 124; $Q$ 529] (Cuv., Vall., Carré; DRAE Ast., Gal., León e Zam.).

Mediocorpo (alcume) "Otro, llamado Mediocorpo, reptaba con las manos" [CNT 489].

Medrar "[...] Los chiquillos nácente y médrante más pronto que los carballos!" [CNT 49].

Meiga "Y se sonrió con su sonrisa mas meiga para acoger al huésped" [CNT 427; $M N$ 163] (Carré; subs. en Rd., Cuv., Vall.).

Meigallos "Andan no sé qué dichos, de que el boticario hace «meigallos»" [CNT 136, 363] (Cuv., Vall., Carré).

Meiguerías "Anda y tira al fuego las meiguerías y la uña de la Gran Bestia" [CNT 364] (Vall., Carré). 
Mercar "Se ahorra [...] para llevarlo [...] y mercar el ternero" [CNT 38, 290] (Cuv., Vall., Carré; vén no DRAE).

Miga ('nada') "Ojo..., habla el señor... ¡No se oye miga!" [MN 278] ("un pouquiño' en Rd., Cuv., Vall.).

Milagre " $¡$ ¿Un milagre, santiñas, un milagre! [CNT 324] (Cuv., Vall., Carré).

Millenta “ ¿No me lo tenedes contado vosotros mismos millentas veces?" [CNT 493] (Rd., Cuv., Vall., Carré).

Millo "Andaba «sachando» el «millo»" [CNT 224] (Rd., Cuv., Vall.).

Min "-A mín, dejádeme de eso..." [CNT 475].

Miña "-A ti no, miña xoya" [CNT 468].

Miñato "El miñato, que mata las palomas" [MN 152] (Rd., Mir, Cuv., Vall.).

Miñoca (alcume) "El Miñoca, ¿no sabe?, ese viejo que..." [CNT 331] (Rd., Mir, Cuv., Vall.).

Misia (contracción de miña señora) "En cuanto a la tía..., misia Gaspara..., era el alma de aquella casa" [CV 660] (Carré).

Mismo” ('xustamente, incluso') “ $¥ M i s m o$ parece cosa de milagro!”, [PU 76] (Carré, mesmo no DRAG).

Mistura "Ni siquiera mistura llevó, que se nos acabó el centeno" [MN 163] (Carré pan de mestura ' el hecho con harina de maíz y centeno mezcladas').

Mocarda" (Santa ...) "Afirmaba que el que no bebe es un pavisoso o una santa mocarda" [CNT 461; MO 799] (mocar 'amolar' en Rd., Cuv., Vall.; Santo Mocardo 'mocoso, indigno de respecto' en Vall.; DRAE “ jugar al santo Mocarro o Macarro" 'xogo de burlas').
Mocas "Había risotadas ofensivas [...] y puños que apretaban mocas y cardeñas" [CNT 298; $T$ 170] (Rd., Mir, Cuv., Vall.).

Moinita "Sí, es, como decimos allá, muy moinita, muy modosa habla tan pacato y $\tan$ suave que a veces no se la oye" [MO 799] (moina 'hipócrita' en Carré, 'raposeiro' en GL; o paso de 'humilde, moi modoso' a 'hipócrita ou falso' explícase facilmente por adoptaren tantas veces os segundos as aparencias dos primeiros).

Mol "¿Qué interesa la cama $\mathrm{mol}$, si quitan el sueño pensares amargos?" [CNT 76].

Molida "Antes de equilibrarse sobre la molida o retorcido circular de paja" [CNT 436] (Cuv., Vall., Carré).

Mollo ('feixe') "Aquí tendrá comida, y cama mejor que el mollo de paja" [CNT 515] (Rd., Cuv., Vall., Carré).

Mómara “-¡iMujer..., y no le haces subir! Anda, despabílate ya [...] ¡Qué mómara! ¡Menéate!" [MN 289] (mómaro I.I. 'xigante que sae polas rúas nalgunhas festas', Carré 'mascarón, espantajo, gigantón o figura extravagante').

Moneco "El moneco, sin embargo, tenía gran parte de culpa" [CNT 397] (Cuv., Gl.).

Morena ('bota de viño') "Llevando consigo una reverenda bota de lo añejo, la clásica morena del país" [CNT 233].

Morrer "-Y tú, ¿qué hiciste, gallego? [...] / - ¿Yo? [...] Yo..., ¡morrín en todas las batallas!" [CNT 297] .

Morriña "Presa de un mal indefinido, una especie de morriña invencible" [CNT 234; $M N$ 109] (Vall., Carré; vén no DRAE). 
Mosa ('moza') "Porque un hombre eche un chisco y coja una baraja y le guste una boena mosa..." [CNT 493].

Moura (pena) (topónimo) [S 125].

Muiñeira "Éstas le pidieron a voces otra música-Nieves, ¡la muiñeira!" [CV 772] (muiñeira en Cuv., Vall., Carré).

Muller ¡Ya lo sabía yo, muller! [CNT 429, 376].

Muñeira "El gaitero entró entonces, seguido de su tamborilero, preludiando la muñeira mariñana" $[Q 549 ; P U$ 53].

Nácaras ("Lapas, nácaras y conchuelas") [S 126] ('caranguexos' en I.I. e RP).

Nadal "Bien pudiera casarse con ella allá para Nadal" [CNT 462] (Sarm., Rd., Mir., Cuv., Vall; antigo no DRAE).

Náparo "Esas uvas gruesas conocidas en el país por náparo o Jaén" [CV 709] (Carré).

Nené "Este rey tenía una 'nené' bunita, bunita como la flor de mayo" [PU 280] (I.I.).

Neno "Alguna salerosa [...] que le estorbó el neno y le soltó allí para que se muriera" [CNT 396; MN 126] (Rd., Cuv., Vall.).

Neto (de viño) "Traerás un neto de vino de lo mejor, ¿eh?" [Q 142] (Cuv., Vall., Carré).

Ninguén "Y si las gasto, no se las debo a ninguén" [CNT 290, 472] (Rd., Cuv., Vall.).

Niño (temos aquí un uso metafórico baseado no niño das aves) "La madre no podía hacer más que niños, o sea la envoltura del cigarro", [T 94].

Non "-Médico «non» sirve. ¡La tierra me llama por el cuerpo!" [CNT 179] (Carré).
Nordés "Es preciso que sea un día que sople vendaval, porque con él se ve más lejos que con el nordés" [CNT 158] (Carré).

$\tilde{\boldsymbol{N}} \boldsymbol{a}$ (aférese de 'señora') "La mujer, «ña» Gregoria, canosa...” [CNT 490] (Carré).

Onde "Sabemos que está escondido mucho dinero en la casa. ¿Ónde?" [CNT 81] (Cuv., Vall., Carré).

Orvallo "A todo esto, el agua menuda de antes, el frío orballo, iba convirtiéndose en lluvia seria" [CNT 43] (Rd., Cuv., Vall., Carré; vén no DRAE, pero Cor. salienta a liñaxe occidental da raíz).

Pacencia "Pacencia y dormire" [CNT 364] (Carré).

Pacheca ('molestia') [S 11] (Vall., Carré, I.I.).

Pajes ('cestos') “A los siete años vendía «pajes» de camarones" [CNT 201] (Vall., Carré).

Pancho " - ¿No ha de nadar? Como un «pancho» [CNT 531] (Carré).

Panela ('patela') "Un costumbre de cuando ganaba mi vida con la sardina... Todo el santo día [...] por las carreteras, con la panela en la cabesa" [CNT 494] ('tixola' en Rd., Cuv., Vall., Carré e GL; 'cesta’ en I.I.).

Pano "Envuelta en el turbante de amarillo pano" [CNT 468] (Rd., Cuv., Vall., Carré).

Pantrigo "Unto en el pote, carne de cuando en cuando, pantrigo a discreción" [CNT 130, 460] (Rd., Cuv., Vall., Carré).

Papai "Decían al molinero y a la molinera papai y mamai" [CNT 129] (Cuv., Gl.).

Papamoscas "Abría y cerraba la boca, haciendo chocar las mandíbulas, como 
los papamoscas de las catedrales" $[P U$ 280] (Cuv., Es.).

Parola "No tenéis de hombres sino la parola" [CNT 134].

Parolar "Buscaba la fala a la mocita. Sentado cerca de ella, le parolaba tan bajo..." [CNT 461; PU 17] (Mir, Cuv., Vall., Carré).

Parolería "-Cuartos, cuartos, y no tanta parolería” [T 243].

Parva "Vinieron a reclamar su parva o desayuno", [PU 55] (Carré, Gl., DRAG; vén no DRAE).

Parvo "-Callade, parvas de vosotras" [CNT 75, 77, 311] (Vall., Carré).

Pás-pa-llás "El canto rimado del ipás-pallás! en el barbecho" [MN 118] (paspallás en Carré).

Pataca "No tiene más que unas pataquitas crudas" [CNT 110].

Patela "Era una pescadora de Areal, de retorno, con su patela ya vacía" [ $Q$ 517] (Cuv., Vall., Carré).

Patexo ('caranguexo pequeno') "El mainzo, este año, por falta de lluvias, iba a perderse. El patexo andaba demasiado caro" [CNT 471] (Carré, RP).

Patrucio "Este modo de entender la autoridad paterna nos alarmó un poquillo. [...] Comunicamos a Cibrao las órdenes del «patrucio»" [CNT 178] (Gl.).

Pauliña "Es capaz de echamos en misa una pauliña" [CNT 139] (Cuv., Vall., Carré).

Pedriscada "Otra madre y su progenitura la gallina pedriscada, que desde la víspera se pavoneaba con un rol de veinticuatro pollitos" [CNT 449] (constatamos na fala oral vaca pedriscada 'pinta', en falantes de Sendelle, Boimorto, Coruña).

Pega "No se ve más cosa viviente que las pegas blanquinegras saltando" [CNT 306, 489] (Cuv., Vall., Carré; vén no DRAE).

Pelouro" ('pedra pequena') "Se le había visto en el playazo jugando a las guijas o pelouros" [CNT 463] (Rd., Cuv., Vall., Carré).

Penalouca (topónimo) "No podía el cura de Penalouca dormir tranquilo" [CNT 476].

Peneira "¡Invencionistas del demonio, que armaban un cuento en el aro de una peneira!" [CNT 362] (probablemente a frase tamén é popular: a peneira aparece noutras locucións como bailar no aro dunha peneira).

Pequerrucho "Lograré yo averiguar quién fue la grandísima perra que soltó a este pequerrucho cerca del arroyo" [CNT 399] (pequerrecho en Carré, co sufixo -ucho en falantes de Currelos, Lugo).

Percudar "La moza no cesaba de percudar, esperando siempre el indicio" [CNT 361] (parece cruzamento de percurar e pescudar, ambos en Carré; pescudar vén no DRAE como desusado).

Perrencha "El niño resistió a este régimen, y hasta a los sorbos de vino que le atizaba, para consolarlo, en sus perrenchas..." [CNT 396] (Mir, Cuv., Vall., Carré).

Perrera ('pelo na fronte') "La muchacha, con su perrera pegada a la frente por grandes churretazos de goma" [I 58] (Gl., I.I.).

Perto "Y la semana pasada, en Gundariz, perto de Armellas, anduvieron con él a pedradas" [CC IV/152] (Carré).

Pescada "La de más allá volvía con una pescada, cogida por las agallas", [T 214] (Rd., Cuv., Vall.). 
Pescantinas "Las más veces rehusaban las pescantinas la cosecha de Cipriana" [CNT 339 T 212] (Cuv., Vall., Gl.).

Peto "Sus ahorritos [...] ya debían encontrarse temblando; valía más no enterarse del estado del peto", [CV 664; CNT 94] (Rd., Cuv., Vall., Carré, DRAG).

Petrucio "Entre los mozos rifadores, los sesudos viejos petrucios..." [CNT 298, 402] (Cuv., Vall., Carré).

Picachón "Le partí la cabeza con el picachón” [CNT 95] (Gl.).

Pifón ('viño frouxo') "Amén del caldo, un vaso de pifón y sardinas asadas" [CNT 509; $Q$ 155] (Cuv., Carré).

Pilo ('lugar para a salmoira das sardiñas') "El salobre vaho de la sardina embanastada o salmorándose en el pilo" [CNT 514]; en [ $Q$ 142] parece estar lexicalizada a expresión sardinas del pilo ('vasilla de madeira' en Gl., 'morea' en I.I.).

Pillaván "La paliza que le atizaron al volver de la feria los pillavanes para robarle" [CNT 351] (Carré; DRAE Ast. e León).

Pinga (echar una) ('beber') "La pícara costumbre, que iba arraigándose, de «echar una pinga» en la taberna" [CNT 130] (pinga en Rd., Mir, Vall.).

Píntiga (alcume) "Llamaban Píntiga, nombre que dan en el país a cierta salamandra" [T 183] (Cuv.).

Piperetes ('manxares saborosos, lambonadas') "Perdía el apetito, no obstante los piperetes con que Mariña me regalaba" [CNT 332; $Q$ 520; $S$ 138] (Carré, Vall., Gl., I.I.; oído a falantes de Lugo).
Piquetaso ('golpe dado coa piqueta') "El negocio no está en dar tanto piquetaso, sino en arrincar de cada golpe buena pella" [CNT 72] (piqueta en Gl.).

Plagas (parécennos galegas as frases "las plagas caen siempre" [CNT 378], e "echar plagas": "La infernal bruja, ocupada sin duda en echarles cuantas maldiciones, plagas, conjuros..." [MN 184]; pénsese que en galego mesmo hai verbos co significado específico de botar pragas: praguear en Rosalía -Follas Novas-, praguexar en Carré).

Pobretalla ('multitude de mendigos') "Los domingos, toda la pobretalla de los antiguos compañeros de Finafrol" [CNT 525] (está formada sobre o modelo de xentalla, cun sufixo apreciativo, pexorativo; xentalla en I.I., xentualla en ER).

Poldras ('pedras planas para pasar o río') "Toda la anchura del río, que allí era mucha, cortándola a modo de irregular calzada las pasaderas o poldras" [MN 189, 188] (Cat. 408, Rd., Cuv., Vall., Carré).

Poma "Un lecho de poma, hojas de maíz seco, con las cuales rellenan en el país los jergones" [CNT 438, 487] (Rd., Cuv., Vall., Carré).

Pomba “¿Cómo se dice paloma en gallego? / -[...] Se dice pomba" [MO 818] (DRAG).

Porta "Y entré por una porta y salí por otra" [PU 280] (DRAG).

Pousar "Pouse el feixe, muller" $[$ CNT 376].

Pra "Tenedes mal curazón pra metervos con quien no se mete con vosotros" [CNT 461] (Carré). 
Pucho "El rapaz continuaba con su pucho encasquetado" [MN 164; PU 211] (Rd., Mir, Cuv., Vall.).

Punteiro "La gaita, cuyo punteiro caía sobre los rojos flecos del roncón" [PU 51, 53] (Rd., Cuv., Vall., DRAG).

Queiroas ('planta de montaña') "Humeante fuego de queiroas y rama de roble" [CNT 240] (Pon., Rd., Cuv., Vall.).

Quina ('nome para chamar á porca') "-Quina, quiniña..., cuch, cuch" $[M N$ 299] (Rd., Cuv., Vall.).

Quizásmente "No le saberé decir con eusautitú... Quizásmente que aún no tendrá voltado" [MN 256].

Rabeno "Cuidé que era el Rabeno [...]. Es un hombre muy malo, que mata a la gente y le saca los untos" [CC IV / 152] (Carré).

Rabuñar "Yo sentí como si me «rabuñasen» con un alfiler nada más" [CNT 268] (Rd., Cuv., Vall., Carré).

Ramalla "Le transportó a lo más oculto del pinar, depositándole sobre un lecho de ramalla seca" [CNT 98, 306, 376] (Carré).

Ramo Cativo ("enfermidade mental, histerismo') "La mocita a quien le había dado sombra de gato negro o atacádola el ramo cativo" [MN 254, 293] (Carré).

Rapariga "De los mozos escapa; pero si encuentra sola a una rapariga..." [CC IV / 153] (Carré).

Rareo ('acto de rarear un souto') "-Yo tengo ahí que atender al rareo del soto" [PU 78] (I.I., rarear no DRAG).

Rato "Conocido en el país por el alias de Bico de rato (hocico de ratón)" [PU 198]; “-Mira, ratiño, en primer lugar tengo que advertirte que..." [MO 808] (rato no DRAG).

¡Recacho! "iQué cena, recacho, qué convite!" [CNT 39] (como subs. en Carré).

Recender "Una olla de castañas cocidas [...] recendiendo a anís" [CNT 63] (Rd., Cuv., Vall., Carré).

Refutrar (forma intensificadora creada a partir de futrar, verbo que figura neste elenco) "Me futro y me refutro en ellas" [MN 263].

Regalía "Los mil encantos que acrecentaban el mérito de tan preciosa regalía" [T 198] (Carré; vén no DRAE, inda que con significados máis específicos ca no galego, onde ten, a maiores, un valor xenérico de 'cousa boa, regalo', así en Dieste, en AO, e témolo oído en Valencia do Sil).

Repinicar "- ¡La riveirana, por Dios! [...] -¿Quién la repinica? [...] -Teresa Molende... ijuy! Da gusto vérsela bailar" [CV 772] (co valor de 'tocar un instrumento musical' é voz común e rexistrámola en moitos diccionarios galegos, tanto na forma usada aquí como na variante repenicar; no texto parecíanos que significa xa 'bailar', pero á vista de que esa acepción non a documentamos e tendo en conta que na novela os dous danzantes tocan, á par que bailan, as castañolas, conviñemos en que, efectivamente, "repinicar a riveirana" é ila marcando ou punteando, ben cos pés, ben cos instrumentos musicais) (DRAG).

Repinico ('tipo de baile') "En el corro aldeano se cuchicheaba el caso era de apuro. ¿Quién iba a bailar el repinico aquel año?" [CNT 350] (repinico, con varios significados, en Carré e ER). 
Rescender "Te voy a echar el caldo en la cunca... Mira cómo resciende" [CNT 92] (Cat.).

Reseso "Una libra de pan reseso" [CNT 39] (Cuv., Vall., Carré).

Resolio "Uno la convida a rosquillas; el otro, a resolio" [PU 64] (Rd., Cuv., Vall., Carré).

\section{Riba de [Q 547] (Carré).}

Ribeirana", riveirana ('tipo de baile') “-Nieves, ¡la muiñeira! -¡La riveirana, por Dios!” [CV 772; CNT 461; PU 150] (Cuv., Carré).

Rifadores "El hecho de no haberse afrontado los comprometía seramente entre los mozos rifadores", [CNT 298] (vén no DRAE).

Ril "La fuente de arroz con riles" [CNT 62] (Rd., Cuv., Vall., Carré).

Rinchón "-¡YY le traen a don Victoriano el caballo del alguacil! [...] ¡Rinchón como un demonio!" [CV 686] (Carré).

Riola "Pasábase la vida en el molino [...], y de riola, fiesta, canto y repiqueteo de panderetas" [CNT 129] (Vall., Carré; Fras., $n^{\circ} 1085$ ).

Rir "-Rite, rite...Quiera Dios no llores tú" [CNT 469] (Mir).

Rolada "Veinticuatro pollitos [...]. ¿Qué rolada de gloria!" [CNT 449] (Carré).

Roncón "Cuyo punteiro caía sobre los rojos flecos del roncón" [PU 51] (Cuv., Carré).

Rosmar " ¡Y también «rosmaba» Nordés, después de caerle tal chiripa de convites!" [CNT 525] (Cuv., Vall., Carré).
Roxo "En la aldea la llamaban roxa, pero en el sentido de rubia" [CNT 126] (Carré, ER, DRAG).

Rueiro "Las mujerucas del rueiro habían revestido la puerta con colchas" [CNT 322, 400] (Cuv., Vall., Carré).

Rufo "Era un viejo de los que aquí llaman "rufos», colorado, listo como un rapaz" [CNT 188, 378; MN 26; MO 837] (Rd., Cuv., Vall., Carré; o DRAE dá acepcións próximas en León e Aragón).

Rula "Cibrao, amoroso como una rula (tórtola)" [CNT 176; PU 203] (Rd., Cuv., Vall., Carré).

Rustrir "-Debimos cogerlo y rustrirlo en aceite" [T 243] (Cuv., Vall., Carré; vén no DRAE referido ao pan).

Sabia ('especie de curandeira') "La condenada bruja de la Sabia" [PU 70] (Vall., Carré).

Salamántiga "Sería una «salamántiga», o no sé qué bicho venenoso" [CNT 243] (Cuv.; DRAE: Extremadura e Salamanca).

Salmántiga "Le llamaban la salmántiga, y el vaho de su aliento empozoñado acarreaba la muerte" [CNT 468] (Carré).

Salmorar "La sardina embanastada o salmorándose en el pilo" [CNT 514] (parece formado sobre o galego salmoirar (Gl.) ou salmoeirar (I.I.)).

Salsa "Su biberón para el destete, la amarga «salsa»" [CNT 201] (Carré 'agua de mar').

Samo "El olor del samo en flor" [CNT 407] (Sob. 244, I.I.).

Sapo "Y sobre el pecho refulgirá la patena, conocida por «sapo»" [CNT 274] (Carré). 
Saudades "Cuando tocaron a separarse, los dos chiquillos cayeron malos qué sé yo de qué..., de una cosa que aquí llamamos saudades" [MN 109] (Cat. 362, Rd., Cuv., Vall., DRAG; DRAE lusismo).

Saudoso "Recordó todo el saudoso ayer" [CV 682; CV 762] (Carré, DRAG).

Sedán "Ancho «mantelo» de brillante sedán franjeado de panilla" [CNT 274] (Carré).

Seide "Cual si de la contemplación apasionada del seide y del fanático pudiese salir algo de asimilación" [ $Q 285$; $P U$ 256] ('fanático' en FG e Carré; I.I. engade 'axente dos crimes dunha persoa').

Sella "Equilibra en su cabeza la sella para ir a la fuente por agua" [CNT 273; $T$ 213] (Cuv., Vall., Carré).

Silbarda (tipo de planta) "Una escoba, fabricada por él con mango de palo de aliaga e hisopo de silbarda" [CNT 440] (Sob., Carré).

Silvas "Dura más que las silvas en los vallados" [CNT 493] (Rd., Cuv., Vall.).

Sobrado "Una escalera de madera conducía al sobrado o cuarto alto" $[M N$ 18] (Carré; DRAE, arcaico).

Soleado ('insolación') "Lo que tiene no es sino eso que le dicen allá en nuestra tierra un soleado" $[I 9,11 ; M N$ 142] (soleada 'insolación’ en Gl.).

Soletrar "Los marineros, se encargaban de soletrarle a Marina las cartas de Adrián" [CNT 183] (Carré; soletrear en Vall.).

Suriña “¿Cómo se dice paloma en gallego? -[...] Se dice pomba y también se dice suriña" [MO 818, 898] (sura en Carré).
Tala "Una pierna tiesa del terrible aparato que acababan de colocarle, y consistía en más de una docena de talas o astillas de caña de cortas dimensiones" [MN 106] (I.I.).

Tallo "En vez de irse, se sentó en un tallo" [CNT 368; MN 162, 256] (Rd., Cuv., Vall.).

Terongueo "Ella reía con un terongueo de paloma que arrulla" [CNT 305] (pódese poñer en relación con torguear, 'vocear, berrar' en Carré e I.I.).

Terra "Gente aldeana de aquella terra nuestra" [CNT 216], "Jubílate y volvámonos a la terriña" [MO 782, 860] (DRAG).

Testo ("enhiesto, gallardo" segundo o vocabulario da autora) "A ver qué testos y guapos estaban los pinos viejos" [CNT 171] (Carré, Gl.).

Tojal "Otros a su edad tienen cada espalda y cada barbota negra que parece un tojal" [MO 797] (DRAE, DRAG).

Tojo “-Entonces, el rapaz, encontrástelo detrás de un tojo, ¿eh?" [CNT 396] (Cuv., Vall; Cor. refírese á nosa palabra como "voz regional del Noroeste").

Tolear "Les llega la de andar tras de las mozas, y andan que tolean" [MN 28] (Vall., Carré, DRAG).

Tolena "Mozallones desvergonzados que salían de tuna y se recogían antes del amanecer, temerosos de una tolena de sus padres" (I.I. 'tunda, malleira').

Tolerías "Señor mi amo, las tolerías de la mocidá son una cosa..." [CNT 474] (Carré).

Tolo "Era un borrachón y se volvió tolo de la bebida" [CNT 461] (Rd., Mir, Cuv., Vall.). 
Traballar "No traballa, no jala del remo, como hacemos los más" [CNT 367] (DRAG).

Trapela" ("trampa aberta no piso para gardar algo') "Tiene una «trapela», y que muchacha que entra y pone el pie en la «trapela», iplas!..." [CNT 139] (Cuv., Carré).

Trasno "Preguntas relativas a trasnos, brujas..." [CNT 242] (Cuv., Vall., Carré).

Tremar ('suxeitar') "Hace falta quien treme del animal" [MN 19] (Carré).

Trenco (alcume) "Martín el Trenco" [CNT 420] (DRAG).

Triga (paja) "Al pobre que anda a las puertas sábele bien el saco relleno de paja triga” [CNT 509] (Carré “Triga (palla)").

Trova ('pelo longo, guedellas', en falantes da cidade de Coruña; polo que sabemos, aplícase só ós homes) "con su plateada trova, enrollada alrededor de un rostro oval..." [ $Q$ 335], "según su retrato, tenía una figura romántica, con trova, $a$ faire rêver" [Q 460, T 98] (non figura en ningún diccionario que nós saibamos, salvo en Fras., $n^{\circ}$ 981, mais é unha palabra relativamente común na cidade herculina).

Tulla "Esperando a que vendiese el centro de la tulla y los bueyes" [CNT 164; $P U$ 135] (Cuv., Vall., Carré).

Uces "Una liebre salió por pies de entre las uces" [CNT 307; CV 657] (Rd., Cuv., Vall., Carré).

Umbelas "Las locas gramíneas alzaban sus airones [...]; las biznagas desplegaban su blanca umbela" [Q 512; $S$ 144] (I.I.).

Vaca loura "La negra coraza y cuernos de las vacas louras" [MN 186] (vacaloura en Carré e no DRAG).
Vel(a allí) "Me parece que ahí la tienes. ¡Vela allí!” [MN 119; PU 277] (Carré Vel', DRAG velaî).

Vent(e)ar ('agoirar, presentir') "Y jura que el dicho perro «ventaba» su muerte" [CNT 179; PU 186; MO 900] (Rd., Cuv., Carré).

Verdade "Será verdade, cuando usted lo dice" [CNT 368].

Verme “ ¿Llega la enfermedad, [...] у yа no se diferencia el verme del hombre!" [MN 27; MO 848] (Rd., Cuv., Vall., Carré, DRAG; o DRAE remite á zooloxía).

Vieiteiro "El olor fecundo, penetrante, que derraman los blancos ramilletes del vieiteiro" [CNT 55] (Rd., Cuv., Vall., Carré).

Vila "Allá en la vila guísase de otro modo" [PU 118] (Rd., Cuv., Vall., Carré, DRAG).

Villa "Dando la vuelta a la llave y acercando a la villa la taza de Gabriel" [MN 232] (Carré, DRAG billa).

Vimio "Ella, guiando con una varita de vimio larga y flexible" [CNT 57] (Cuv., Vall., Gl.).

Vinculistas ('vinculeiros') "Poco a poco, de vinculistas desahogados, los Reigal se habían convertido en labriegos" [CNT 490] (vinculeiro en Vall. e Carré).

Vinte ('numeral cardinal') "Vinte años que faltas de Seigonde..." [CNT 426] (Carré).

Virar "¡Cosas de la «fertuna», que «vira» como el viento!" [CNT 187, 199] (Mir, Cuv., Vall., Carré).

Voltar "Que salió tempranito con Manola... Que no voltaron aún" [MN230] (Carré). 
Vos "A ver si vos calláis" [CNT 268].

Vós "¿Vístedes vos el camino de fierro?" [CNT 97].

Vustede "Para servir a vustede, señorita Manolita" [MN 17, 27].

Xardas "Una tarde que salí yo en Marín a la pesca de las xardas..." [MO 860] (DRAG).

Xeste ('albaroque, costume de celebrar o remate dun edificio', é título dun conto) "La cena solemne del xeste, el banquete extraordinario ofrecido desde la primavera para el día en que terminasen las paredes del nuevo edificio" [CNT 39, 38; $Q$ 544] (Carré).

Xoya “-A ti no, miña xoya..." [CNT 468] (a locución aparece en Carré).
Zoar [S 131] (Rd., Cuv., Vall., Carré).

Zonchos (de hierro) "El arca del viejo era de las mayores, pero también de las más mugrientas y desvencijadas traía remiendos de madera nueva y zonchos de hierro torpemente aplicados" [CNT 252] (zoncho 'abrazadera de hierro de la rueda del carro' en Gl.).

Zopillar ('salucar' ou 'impar') "Cándida no penaba tanto [...], pero la sacudía el zopillar angustioso. -Calla, mujer, calla; ya hiparás después..." [CNT 316] (debe estar formado sobre a raíz de zopo 'torpe, que tropeza' (Cuv.), e sería unha clara metáfora, polo son entrecortado). 